The Performance of Japanese Mutual Funds

\author{
Jun Cai, K.C. Chan \& Takeshi Yamada
}

Working Paper No. 108

\author{
Department of Finance \\ School of Business \& Management \\ The Hong Kong University of Science \& Technology \\ Kowloon, Hong Kong
}

This paper was presented at the conference Emerging Trends in Japanese Financial Markets held at Columbia University on December 8-9, 1995. The conference was sponsored by the Center on Japanese Economy and Business and organized by Professor Yasushi Hamao

\author{
Working Paper Series \\ Center on Japanese Economy and Business \\ Graduate School of Business \\ Columbia University \\ February 1996
}




\title{
The Performance of Japanese Mutual Funds
}

\author{
by \\ Jun Cai, K. C. Chan, and Takeshi Yamada
}

January 1996

\author{
Department of Finance \\ School of Business and Management \\ The Hong Kong University of Science and Technology \\ Clear Water Bay, Kowloon, Hong Kong \\ Email: fnjuncai, kcchan, tyamada@usthk.ust.hk \\ Tel: +852-2358-7666 \\ Fax: +852-2358-1749
}

First draft: November, 1994

The authors acknowledge the seminar participants at the Chinese University, the City University of Hong Kong, Hong Kong Statistical Association, the Hong Kong University of Science and Technology, and participants at the American Finance Association Annual Meeting in San Francisco, Emerging Trends in Japanese Financial Markets Conference at Columbia University, the Japan Financial Economics Association Annual Meeting at Yokohama National University, and Kinzai Finance Workshop. We particularly thank Wayne Ferson, Bill Goetzmann, Yasushi Hamao, Katsuhide Hatanaka (LTCB Investment Advisory Co.), Ravi Jagannathan, David Modest, Rudi Schadt, Osamu Shigeta (Daiwa Investment Trust), Toshinori Takayama (MTB Investment Technology) and Koichi Watanabe (Daiwa Investment Trust) for valuable comments, and the Investment Trust Association for providing us with valuable information. The usual disclaimer applies. 
The Performance of Japanese Mutual Funds

\begin{abstract}
We analyze the performance of Japanese open-type stock mutual funds for the 1981-1992 period. The results show that, regardless of the performance measures and benchmarks employed, most of the Japanese mutual funds underperform the benchmarks by between $3.6 \%$ to $10.8 \%$ per annum. These funds tend to invest more in large stocks with low book-to-market ratios. But this feature does not explain the underperformance. A potential explanation is the dilution effect caused by inflows of funds. In Japan, a new investor of an open-type fund only pays in the after-tax value of the net asset value. We conduct a bootstrap experiment to assess the magnitude of this dilution effect.
\end{abstract}


The overall performance of Japanese open-type stock mutual funds over the last fifteen years has not been impressive compared to that of the market. ${ }^{1}$ The average rate of return of 800 open-type mutual funds was $1.74 \%$ per annum between January 1981 and December 1992, while that of the market was $9.28 \%$ per annum during the same period. Regardless of the performance measures and benchmarks employed, we find strong evidence of underperformance in the Japanese mutual funds.

It has been suggested that the meager performance of Japanese mutual funds may be due to institutional factors such as the contracts between fund managers and their employers as well as the relationships between mutual fund companies and brokerage houses. (See, for example, Economist (1994).) Major mutual fund companies are subsidiaries of the brokerage houses from which top management as well as many fund managers are drawn. The fund managers' salaries are paid from the fixed commissions that investors pay to the mutual fund companies. However, their salaries may not be directly linked to their investment performance. They are usually tied closely to the pay scale of the parent company which may be unrelated to each manager's performance. Good performance of a manager may result to a certain extent in quicker promotions or higher bonuses, but the link is not as explicit as in the United States. Such a compensation scheme may create an agency problem between the fund managers and the investors. According to the Economist (1994), the turnover ratio in Japanese mutual funds was more than twice the Tokyo market average during the 1980s. A high turnover ratio produces profits for the parent brokerage houses due to the fixed commissions for stock trading. Finally, major brokerage houses like Nomura, Nikko, Daiwa and Yamaichi recommend stocks for their clients. These recommendations may influence the selection of the stocks by the subsidiary mutual fund companies. The Japanese Ministry of Finance has been aware of the poor performance of the mutual funds and has come up with several ways to bring more competition into the business as well as to disclose more information to investors. First, the Ministry has permitted banks and foreign companies to manage mutual funds since 1990. Second, the Ministry intends to promote comparisons of funds' performance so that 
investors can make informed choices. At present, mutual fund managers are not allowed to compare their performance with rivals' in advertisements. Finally, since June 1994, fund managers have to disclose their commissions.

We provide the first comprehensive study of Japanese mutual funds. Our sample covers the open-type stock mutual funds managed by nine investment management companies for the 1981-1992 period. We employ the traditional Jensen Measure [see Jensen $(1968,1969)$ ] as well as the Positive Period Weighting Measure developed by Grinblatt and Titman (1989b, 1993). Following Ferson and Schadt (1994), we incorporate conditional information directly into the performance measures to control for the biases arising from fund managers responding to public information. Further we investigate what kinds of strategy funds have followed in general. To this end we construct mimicking portfolios based on size and book-tomarket ratios, and explore if any of the performance found in the previous section can be explained by the weighting on these factors.

In order to obtain valid inferences with various performance measures, the benchmark must be mean-variance efficient from the point of view of the uninformed investors. We employ two different benchmarks. The first one is a value-weighted single-index benchmark which covers stocks listed on both the first section and the second section of the Tokyo Stock Exchange (TSE), government bonds, corporate bonds and convertible bonds. The second benchmark consists of three factors: (1) the value-weighted market factor as described above; (2) a mimicking factor that is related to the size effect; and (3) another mimicking factor that is related to the book-to-market ratio. We find evidence that the three-factor benchmark is more appropriate than the single-index benchmark. However, our general conclusion is not affected by the choice of benchmark.

We also evaluate the dilution effect on the net asset value of open-type funds. This effect is caused by a particular method according to which the sales price of a mutual fund share is calculated when there is an inflow of funds. Essentially, in the case of an outflow, the fund pays out net asset value (NAV) to the investors so that the NAV per share is unaffected by the 
outflow. The investors pay capital gains tax, if any, from the proceeds. However, in the case of an inflow, new investors do not pay in the amount equal to the NAV per share. Instead, they pay in the after-tax value of NAV, which is the same amount as what existing investors would receive if they sold the share. Therefore the NAV per share is diluted by the inflow. This implies that the rate of return on the NAV is negative even if the return on the managed portfolio is zero.

The paper is organized as follows. Section 1 gives an introduction to Japanese mutual funds. Section 2 provides a comprehensive performance evaluation using various measures. This section also examines whether performance varies between different periods, whether any management company or companies performed better (or worse) than the others, and whether there is any persistence in performance among the managers. Section 3 analyzes how funds were managed and investigates their performance by using the mimicking portfolios based on size and book-to-market ratios This section also refers briefly to funds' timing ability. Section 4 provides a simulation analysis of the dilution effect. Finally, the last section presents the conclusion.

\section{The Japanese Mutual Funds}

\subsection{Overview of the mutual fund industry}

The Japanese mutual funds are of the contractual type, not of the corporate type which prevails in the US; thus the Japanese mutual funds are called investment trusts. A contract is made between an investment trust management company, a trustee (a trust bank), and a beneficiary (an investor). The cash collected from investors by management companies, through subscriptions or sales of beneficiary certificates, are transferred to the custody of a trustee company. The manager gives investment instructions to the trustee which administers and safe-keeps the assets. ${ }^{2}$ The administration fee of the trust bank is passed on to the investors as a debit subtracted from the net asset value of the mutual fund (or investment trust). In most 
cases an investor of an open-type mutual fund is required to pay a fee up front as a fixed percentage of the value of the investment.

At present in Japan, there are 16 domestic, 5 foreign-affiliated and 5 bank-affiliated investment trust management companies. ${ }^{3}$ However, a major portion of the investment trusts sold in Japan has been run by management companies that are subsidiaries of Japanese brokerage houses. Many of these management companies originate from the investment trust division of the brokerage houses, which originally managed their own investments. The management company delegates subscriptions and sales of the investment trusts to brokerage houses; at present, the majority of funds are sold through brokerage houses that are parents of the fund management firms. A small portion of funds managed by foreign- or bank-affiliated companies is sold by brokerage houses that are not affiliated with the management companies, or are sold directly by the management firms. The sample we use includes only those funds that are sold by the parent brokerage houses because most of the other types of funds did not start operation before 1990.

Depending on the portfolio structure, investment trusts in Japan can be classified into two kinds: stock investment trusts and bond investment trusts. The latter invest only in bonds and money market instruments. The former, however, invest not only in stocks but also in bonds (including convertible bonds and warrants) and the money market. According to the investment policy of the funds, stock investment trusts are broadly classified into three categories: growth type, stable growth type, and stable type. The growth type typically has no upper limit on the proportion that the fund can invest in stocks, whereas the stable growth type does have such limits. The stable type mainly invests in convertible bonds. ${ }^{4}$ At the end of 1992, the portfolio weights of stocks, bonds and other money market instruments in stock investment trusts were 50.2\%, 17.6\%, and 26.5\%, respectively. (See Investment Trusts Association (1994).) The investment trusts in Japan can be grouped into the open-type and the unit type. The former allows additional flow of funds into the trust property after the fund's 
institution, while the latter does not. We focus on the open-type investment trusts because unit-type funds operate only for about five years.

The investment trusts in Japan represented about 3.5 percent of financial assets of the household sector as of the end of 1992.5 This figure includes both stock and bond investment trusts as well as both open-type and unit-type investment trusts. At the end of the same year, investment trusts had approximately 43 trillion yen in aggregate assets, of which 21 trillion was in stock investment trusts. The following numbers summarize the stockholdings of the funds during 1992. The total market value of stocks held by the funds was 10.1 trillion yen or 12.5 million shares, which amounts to $3.4 \%$ and $3.6 \%$, respectively, of total stocks outstanding on all stock exchanges in Japan at the end of the year. The stocks traded by the funds during the year, the sum of buys and sells, amounted to 12.2 trillion yen or 13.9 million shares, which represented $15.1 \%$ in value and $16.8 \%$ in volume of the aggregate stock trading. Therefore, the turnover ratio of all funds was $110.7 \%$ while that of the market was $47.68 \%$ during the year.

\subsection{Management fees and taxes}

There are two sources of costs that are borne by investors (or beneficiaries) of the investment trust. The net asset value (NAV) of a fund is determined after deducting these costs from the asset value. The first cost component is a fixed management fee paid to the management company, the trust bank and the brokerage house that subscribes and sells the investment trust security. The amount of the fee ranges from $0.55 \%$ to $1.5 \%$ of the total asset value and the fee is deducted from the total value on a daily basis. The second component is the securities transfer tax plus the brokerage commission which is paid to the brokerage house that executes orders from the management company. This part of the management fee varies according to the amount of turnover. The brokerage commission rates vary from $1.150 \%$ of transactions valued under 1 million yen to $0.100 \%$ of those above 500 million and below 1 billion yen. For transactions over 1 billion yen, the commission rates are negotiable. (These rates were 
amended on June 4,1990.) The securities transfer tax on equity is $0.3 \%$ (since April 1992) of the market price, and is paid by investors when they sell shares.

To provide an estimate of the transaction costs, we need estimates of both turnover rate and average transaction value. From the aggregate data, the annual turnover rate was approximately $110 \%$ for 1992 . Since we do not have data on the average transaction value, we arbitrarily choose a range of commission rates that is plausible for institutional investors: from $0.375 \%$ for transactions valued from 30 million to 50 million yen for the lower range, to $0.100 \%$ for those from 500 million to 1 billion yen for the higher range. Assuming a turnover rate of $110 \%$, the variable portion of transaction cost ranges from approximately $0.72 \%$ to $1.32 \%$ per annum. These figures assume securities transfer tax rate of $0.45 \%$, a rate that had been imposed during most of our observation period. 6 If the fixed management fee is $0.55 \%(1.5 \%)$, the total transaction cost ranges from $1.27 \%(2.22 \%)$ to $1.87 \%(2.82 \%)$.

\subsection{Mutual fund data}

The mutual fund data are obtained from Kinyuu Deta Sisutemu (Financial Data Systems Incorporated) in Tokyo for the period from January 1978 to April 1994. The dataset includes 1,151 open-type mutual funds managed by 26 management companies. Every fund that existed during the period is included; thus there is no survivorship bias. Among the 26 companies, half of them started operation only after 1990. In particular, we chose nine management companies that operated throughout the observation period. These companies

include: Nomura, Nikko, Yamaichi, Daiwa, Taiyo, Shin-Wako, Sanyo, Asahi, and Japan. For individual fund analysis, we select the funds with more than 97 observations from January 1981 to December $1992 .{ }^{7}$ We find 64 funds managed by the nine fund management companies After adjusting the NAV for splits, if any, we calculated the continuously compounded monthly returns with dividend payments for all the funds. ${ }^{8}$ To assess the aggregate performance of the Japanese mutual funds, we construct two portfolios, vw800 and ew800, which are the value- and equal-weighted portfolios, respectively, of all the 800 mutual funds 
run by the nine fund management companies. We also construct both value- and equalweighted portfolios of the 64 individual funds, vw64 and ew64. Since some of these funds concentrate investment in certain industries, foreign equities, or convertible bonds, we construct additional portfolios of funds that primarily invest in well-diversified Japanese equities. We find 190 diversified equity funds among the universe of 800 funds, and 13 among the 64 funds with relatively long history. 9

\subsection{Basic performance}

Table 1 shows that the average raw returns of the open-type mutual funds during the entire observation period (Jan. 1981 - Dec. 1992) were $1.73 \%$ and $2.41 \%$ per annum for vw800 and ew800, respectively. The well-diversified Japanese equity funds (i.e., the 190 and 13 portfolios) show lower mean returns and higher standard deviations than those of the 800 and 64 portfolios. The sub-period figures show that the well-diversified equity funds did particularly poorly in the bear market during the Jan. 1990 - Dec. 1992 period. Comparing the mutual fund returns to various benchmarks, we find that the average performance of Japanese mutual funds underperformed various measures, even after adding back a transaction cost of, say, 5\%.

The first benchmark in the table, the value-weighted index that performed $8.91 \%$ during the full observation period, includes all stocks listed on the TSE, all government and corporate bonds with a longer than one-year maturity, and convertible bonds. ${ }^{10}$ Since Japanese stocktype mutual funds invest not only in stocks but also in bonds and convertible bonds, it is appropriate to compare fund performance with this benchmark. The buy-and-hold 30 portfolio includes the 30 largest stocks as of the end of 1980 . Its return was the highest $(14.85 \%$ for the whole observation period) though its standard deviation was also the largest.

Table 2 provides summary statistics for individual funds as well as for the nine management firms. Note that the returns in Table 2 are reported in terms of monthly returns instead of annual returns. For each company, mean return and standard deviation are reported for equally weighted portfolios of all its funds and for its well-diversified Japanese 
equity funds. With the exception of three management firms (Nomura, Sanyo and Asahi), well-diversified equity funds performed worse than the average of all funds. Among the 64 individual funds, performance varies from $-0.74 \%$ per month $(-8.87 \%$ p.a. $)$ to $0.94 \%$ per month (11.29\% p.a.), and standard deviation from $1.99 \%$ per month (6.89\% p.a.) to $8.82 \%$ per month ( $30.54 \%$ p.a.). Among the 13 well-diversified equity funds, the mean varies from $-0.25 \%$ per month (-2.98\% p.a.) to $0.94 \%$ per month ( $11.29 \%$ p.a.), and standard deviation from $3.85 \%$ per month (13.33\% p.a.) to $5.93 \%$ per month (20.54\% p.a.) Although the observation periods for the funds are not exactly the same, they overlap during the majority of the period. (Figure 1 shows a plot of mean return against standard deviation of individual funds.)

\section{The Performance}

\subsection{Performance measures}

\section{Jensen Measure}

Suppose $r_{j, t+1}$ is the monthly return of the mutual fund, $j$, in excess of the one-month risk-free rate, and $r_{m, t+1}$ is the excess return on the mean-variance efficient market portfolio; then the Jensen Measure refers to the intercept $\alpha_{j}$ in the following regression:

$$
r_{j, t+1}=\alpha_{j}+\beta_{j} r_{m, t+1}+\varepsilon_{j, t+1}
$$

A positive Jensen Measure indicates superior performance if the mutual fund manager possesses stock selection ability but no timing ability.

\section{Positive Period Weighting (PPW) Measure}

When the fund manager also has timing ability, $\alpha_{j}$ can be negative even if the manager was successful both in selecting stocks and gauging market timing. Conversely $\alpha_{j}$ can be positive even if the manager was not successful in both stock selection and timing; see Jensen (1972), Admati and Ross (1985), Dybvig and Ross (1985) and Lehmann and Modest (1987). We therefore calculate the PPW measure developed by Grinblatt and Titman (1989b, 1993) to address the problem of a negative Jensen Measure when a manager has timing information. The PPW measure for fund $j$ is defined as a summation: $\alpha_{j}=\Sigma_{t} w_{t} r_{j, t}$, where $r_{j, t}$ is the excess 
return of the fund for period $t$, and the summation is over the observation period of the data. The weights are chosen to be non-negative and satisfy the following relation for the excess return of a benchmark, $r_{m, t}$, for the same period: $\sum_{t} w_{t} r_{m, t}=0$. This relation corresponds to the first-order condition for holding the optimal benchmark portfolio where the weights correspond to the marginal utility of an investor. To derive these weights, we assume a riskaverse investor with a power utility function who maximizes his expected utility (or the average utility over the sample period), $\Sigma_{t}(1 / \theta)\left(1+r_{f, t}+\gamma_{m, t}\right)^{\theta}$. The marginal utility at time $\mathrm{t}$ is $\left(1+r_{f, t}+r_{m, t}\right)^{\theta-1}$, where the gross return represents the wealth level in each period, assuming the initial wealth is 1 . The risk-free rate at time $t$ is denoted by $r_{f, t}$, and $\gamma$ is the optimal weight of the benchmark portfolio obtained by maximizing the expected (or the average) utility. The time series of the marginal utilities are rescaled so that they add up to 1 ; i.e., $w_{t}=\left(1+r_{f, t}+r_{m, t}\right)^{\theta-1} / \Sigma_{t}\left(1+r_{f, t}+\gamma_{m, t}\right)^{\theta-1}$. We choose the risk aversion parameter, $\theta$, of 0.68 because the optimal portfolio under this parameter setting requires no holdings of the riskfree asset. We calculate each set of weights for different benchmarks as well as for different observation periods.

\section{Conditional Jensen Measure}

Ferson and Schadt (1994) recognize the importance of incorporating changing economic conditions in evaluating mutual fund performance. If fund managers shift their portfolios based on public information on the economic conditions, traditional (unconditional) performance measures that do not take into account of this effect can be biased. By conditioning on time-varying economic variables, Ferson and Schadt (1994) obtain results that are different from the unconditional analysis. In the conditioned model the beta of a managed portfolio is assumed to be a linear function of public information vector $Z_{t}$ that captures changing economic conditions:

$$
\beta_{j}\left(Z_{t}\right)=b_{1 j}+b_{2 j} z_{t}
$$

where $b_{1 j}$ is the unconditional mean of the conditional beta $\mathrm{E}\left[\beta_{j}\left(Z_{t}\right)\right]$. The second coefficient, $b_{2 j}$, is a beta response coefficient vector that tracks how the beta varies with the innovation of 
the conditioning variable vector $z_{t}=Z_{t}-\mathrm{E}\left(Z_{t}\right)$. By multiplying the market return to $\beta_{j}\left(Z_{t}\right)$, the following regression is obtained:

$$
r_{j, t+1}=a_{j}+b_{1 j} r_{m, t+1}+b_{2 j}\left(z_{t} r_{m, t+1}\right)+\varepsilon_{j, t+1}
$$

Since returns are expressed in terms of excess returns from the risk-free rate, the additional factor in (2) can be interpreted as a self-financing dynamic strategy that purchases $z_{t}$ units of market portfolio by borrowing on the risk-free market.

\subsection{Benchmark and conditioning variables}

Since Japanese stock mutual funds invest not only in stocks but also in bonds as well as convertible bonds, we use the value-weighted benchmark that consists of these assets. The conditioning variables are: dividend yield of the value-weighted index, the one-month Gensaki rate, the term spread between the yield on the ten-year government bond and the one-month Gensaki rate, and finally the January dummy variable. Dividend yield for the market is constructed from the difference between the two market index returns with and without dividends provided by the PACAP Japanese database. The dividend yield used is computed by summing the monthly dividends for the 12 months preceding month $\mathrm{t}$ and dividing the sum with the index without dividends for month $t$. The one-month Gensaki rates and the yields on the 10-year government bond are from the Daiwa Institute of Research.

\subsection{Performances}

Table 3 summarizes the results of estimating the Jensen Measure based on both unconditional and conditional benchmarks. The results confirm that Japanese open-type mutual funds significantly underperform the market index. The second and third columns of Panel A show unconditional and conditional Jensen alphas for the aggregate portfolios. The portfolio alphas of funds in the "All Category" are consistently negative and are statistically significant with numbers ranging from $-0.501 \%$ to $-0.587 \%$ per month (around $-6 \%$ to $-8 \%$ p.a.). The welldiversified equity funds did worse, by $-8 \%$ to $-9.5 \%$ p.a. below the benchmark. Even allowing 
for transaction cost as high as 5\%, the funds still on average underperform the index. The second panel shows summary results for individual funds. Almost all funds have negative alphas, with a majority being statistically significant. In particular, all 13 well-diversified equity funds have negative alphas and 11 of them are statistically significant. We examine the alphas of foreign-investment funds to see if they had particularly poor performance due to the appreciation of the yen exchange rate during the observation period. The average alpha of the six foreign-investment funds is -0.425 while that of the domestic-only funds is -0.568 . Thus in our sample, whether or not to include foreign-investment funds does not seem to affect the general result. ${ }^{11}$

In the conditional models, the Jensen Measures do not get better. Figure 2 plots the histogram for the unconditional and conditional Jensen Measures. Both the unconditional and conditional Jensen Measures are skewed to the left. The results contrast with those of Ferson and Schadt (1994) who find that in the US data, the alphas become more positive when using the conditional model. They show that when the covariance between the conditional beta and the excess return on the market portfolio, $\operatorname{cov}\left(r_{m}, b_{2 j} z\right)$, is negative, the unconditional Jensen Measure is negatively biased. ${ }^{12}$ They find this to be the case for the US funds, which explains why they can reverse the negative measure found for the unconditional model. We do not, however, find significant negative correlation between the conditional betas and the excess market return, which explains why our conditional alphas do not get better than the unconditional ones.

The conditional variables, however, have information. For example, the third column Panel A reports the p-value of the F-test for the significance of the information variables for the aggregate portfolios. ${ }^{13}$ The results show that additional conditional variables are significant for explaining the return dynamics of the mutual funds. Panel A also reports the $\mathrm{R}^{2}$ from the two regressions. The conditional variables provide additional explanatory power of $3 \%$ to $4 \%$.

The PPW measures are also negative and similar to the Jensen Measures in size for the aggregate portfolios. With regard to the individual funds, 61 out of the 64 estimates are 
negative from the unconditional model, with 40 being significant at the $10 \%$ level and 28 being significant at the 5\% level. Most of the funds' PPW measures are between $-0.3 \%$ to $-0.9 \%$ per month, or $-3.6 \%$ to $-10.8 \%$ per annum. The results for the well-diversified equity funds are also similar to those of both conditional and unconditional alphas.

Finally, we note that the survivorship bias should not be a major concern for the 64 funds selected for individual analysis. Others have noted that the reliance on surviving funds positively skew the performance measure (Grinblatt and Titman (1989a), Brown, Goetzmann, Ibbotson and Ross (1992)). In our case, however, the 64 funds with relatively long history show worse performance than the overall industry funds (the 800 portfolios) using any measures presented in this section. Therefore survivorship bias may not to be a major issue.

\subsection{Betas}

In the first column of Table 4 Panel A the beta coefficients from the unconditional model range from 0.835 to 0.958 for the 800 and 64 "All Category" portfolios, and from 1.020 to 1.156 for the 190 and 13 "Well-diversified equity" portfolios. The average beta coefficients of the conditional model, $b_{1}$, are shown in the second column of the table. Conditional betas are larger than the unconditional ones. This implies that the unconditional betas may be biased and that managers could be adjusting their portfolios to changing economic conditions. Particularly, the well-diversified equity funds tend to have betas larger than unity and are larger than the average of all funds. However, the mutual fund industry as a whole, represented by the 800 portfolios, has a risk position that is close to that of the market.

Before we look at the sensitivities of the betas to individual conditional variables, we consider whether the same set of information variables can forecast the market returns. We regress the excess returns of the market portfolio one month ahead on the information variables of the current month. All information variables are expressed as innovations from the long-term mean. The regression result shows that the dividend yield $\left(\mathrm{div}_{t}\right)$ is positively 
related, and the one-month Gensaki rate $\left(r g_{t}\right)$ and term spread $\left(s p_{t}\right)$ are negatively related to the excess return on the market portfolio:

$$
r_{m, t+1}=\begin{array}{cc}
4.02+4.57 d i v_{t}-12.92 r g_{t}-16.19 s p_{t}+\varepsilon_{m, t+1} \\
(2.18)(2.95) & (-2.74)(-2.38)
\end{array} \quad \mathrm{R}^{2}=0.06 .
$$

This implies that these conditioning variables have predictive power for the market returns one period ahead. The negative relation between the spread and market index return from the TSE is also found in Campbell and Hamao (1992). If managers use this information in adjusting their portfolios, the portfolio betas should respond positively to a change in the dividend yield, and negatively to a change in the Gensaki rate and the term spread.

The last four columns show the sensitivities of betas to these conditioning variables and the January dummy. Fund managers do respond positively to dividend yield. With regard to the interest rate information, the beta responses are mostly positive, opposite to the prediction that managers use the interest rate information in forecasting the market returns. For individual funds, we observe that the sign for the dividend yield is positive for most of the funds (positive for all well-diversified equity funds), of which about half of them are statistically significant. However, the signs for the short-term interest rate and the term short spread are positive for most of the funds, of which about one-half and one-third are significant, respectively.

The results from both the aggregate and individual funds suggest that Japanese mutual fund managers responded correctly to the information in the dividend yield but incorrectly to the interest rate information. Finally, the signs of the coefficients of January dummies are all negative but not all of the coefficients are statistically significant. Particularly, the coefficients for well-diversified equity funds tend to be less significant.

\subsection{Sub-period and company analysis}

Our observation period, which is from Jan. 1981 to Dec. 1992, covers a long bull market until the end of 1989 and the subsequent bear market. We estimate the performance measures for 
the two sub-periods to determine if they differ between the two market environments. The results of Table 5 show that the performance has not been any better for both sub-periods.

We next check whether the aggregate performance is affected by a few poor performing companies. Table 6 show both conditional and unconditional alphas for the nine management companies for the entire observation period as well as for the two sub-periods. The table covers only the well-diversified equity funds since the composition of other types of funds may differ among companies. Also, we employ equal-weighted portfolios, instead of valueweighted ones, to avoid bias that may arise if large funds perform differently from others. The result shows that even the best performing company (company $\mathrm{A}$ in the table) seems to underperform the index significantly by 5.8 to $5.9 \%$ p.a.

Furthermore, we examine if there is persistence in the performance of nine management companies. Table 6 includes the ranking of the companies from 1 to 9 . We split the periods according to the previous analysis and estimate the Jensen Measures for both unconditional and conditional models. We calculate the Spearman rank correlation between the two periods. The rank correlation of company alphas for the unconditional model is -0.10 , and for the conditional model is 0.00 . We conclude that there is little persistence in performance among the companies.

\section{An Investigation of Managers' Strategies}

\subsection{Passive strategies}

For comparison with the sample of mutual funds, we construct a number of portfolios based on passive strategies that use only known accounting information and no private information about the stocks. The purpose of this exercise is to validate our approach; since these passive portfolios are formed without private information, they should not show evidence of stock selection ability in the empirical models considered by us.

Fama and French (1992) show that two empirically determined variables, size and book-tomarket ratio, effectively explain the cross-section of average returns on the US stocks for the 
1963-1990 period, among other variables like market beta, E/P and leverage. Chan, Hamao and Lakonishok (1991) examine cross-sectional regressions for the Japanese stock market and reach similar conclusions. Also in a time series context, Fama and French (1993) demonstrate that the market factor and the mimicking factors related to size and book-to-market ratio effects successfully capture the common variations in the stock market. Motivated by these results, we construct 36 value-weighted passive portfolios from all stocks listed on the TSE. These include 25 portfolios formed by a two-way sort on size and book-to-market ratios (BE/ME), six portfolios formed on the earnings price ratio $(\mathrm{E} / \mathrm{P})$ and the five portfolios formed on the ratio between book asset and market equity (BA/ME). The first of the six E/P portfolios consists of stocks with negative earnings. The rest of the stocks are broken into five groups, from lowest to highest $\mathrm{E} / \mathrm{P}$ ratios. Since these 36 portfolios do not use private information, they should generate zero intercept when regressed on benchmarks and therefore can provide a basis for comparison with the mutual fund performance. We rebalance the portfolios once a year based on the most currently available information. Most of the Japanese companies have March as the end of their fiscal year, and the annual reports published by the Ministry of Finance become available to the public a few months later. Therefore we construct the portfolio in July when most of the new information first becomes available to the public. When calculating the $\mathrm{BE} / \mathrm{ME}, \mathrm{BA} / \mathrm{ME}$ and $\mathrm{E} / \mathrm{P}$ ratios in July, we use the market values at the end of June, and the accounting values from the previous fiscal year that ends anytime between April of the previous year to March of the current year.

We regress excess returns of the 36 passive portfolios on the excess returns of the market portfolio. The first panel of Table 7 reports the intercepts from the unconditional model. Most of the significant positive intercepts are from the portfolios of smaller size and higher book-tomarket ratios, and a significantly negative alpha is observed for portfolio with the largest size and lowest $\mathrm{BE} / \mathrm{ME}$ ratio. This evidence implies the inefficiency of the value-weighted market portfolio; i.e., one can buy small stocks with high book-to-market ratios to beat the 
performance of the value-weighted portfolio. The second panel of Table 7 summarizes the results for the conditional model which is similar to those from the unconditional regression. ${ }^{14}$

\subsection{Three-factor model}

Based on the findings above, we investigate if underperformance of the Japanese open-type mutual funds stems from investing in large and low BE/ME stocks. To this end we construct factors that represent the two factors described above. First, we construct passive portfolios based on size and book-to-market ratios in a similar manner explained in the previous section. For size-based groups, we use the median to split the stocks into the big and small groups (S and $\mathrm{B})$. For the $\mathrm{BE} / \mathrm{ME}$ ratios, we group the stocks based on breakpoints for the bottom $30 \%$ (low), the middle 40\% (medium) and the top 30\% (high) ratios. Therefore we have six portfolios; i.e., small and large firm portfolios each classified into low, medium and high bookto-market ratios. We use the notation SL, SM and $\mathrm{SH}$ for small firm portfolios with three different levels of book-to-market ratios, and $\mathrm{BL}, \mathrm{BM}$ and $\mathrm{BH}$ for the three large firm portfolios. After forming the portfolios, we calculate monthly value-weighted returns by using the same weights from July of the current year to June of the following year. Next we calculate returns of two self-financing portfolios; one related to size and the other to the book-to-market ratio. The mimicking portfolio that is related to size, SMB, is the difference between the average returns of the three small-stock portfolios (SL, SM, SH) and the average of the three large-stock portfolios $(\mathrm{BL}, \mathrm{BM}, \mathrm{BH})$. The return on the mimicking portfolio should be free of the influence of the $\mathrm{BE} / \mathrm{ME}$ effect and should characterize the return difference between large and small stocks. Similarly, the return of the mimicking portfolio that is related to the book-to-market ratio, $\mathrm{HML}$, is the difference between the average return of two high $\mathrm{BE} / \mathrm{ME}$ portfolios ( $\mathrm{SH}$ and $\mathrm{BH})$ and that of the two low $\mathrm{BE} / \mathrm{ME}$ portfolios (SL and $\mathrm{BL}$ ). The returns of the HML portfolio should be free of the influence of size and should capture the difference in returns of the high and low BE/ME stocks. The correlation between the two factors, SMB and HML, is small $(-0.04)$. 
In the next step we regress the excess returns of various passive portfolios that we constructed in Section 3.1 on the three factors. Most of these passive portfolios do not generate abnormal performance with respect to the three-factor benchmark (not reported). This result implies that the three factors can mimic an efficient benchmark. Similar results have been found by Fama and French (1992) for the US stock market. The explanatory power of the three factors against the passive 25 size and book-to-market sorted portfolio returns are 0.811 on average. The adjusted R-squares is relatively low compared to those results found by Fama and French (1993). The reason is that our market index, or the first factor, includes bonds. When we use the stock index (TOPIX) for the first factor, the average R-square increases to 0.912, which is comparable to Fama-French results. Therefore the size and book-to-market factors are reasonable factors for explaining the equity portion of the mutual funds returns.

Our primary interest is to find whether the underperformance that has been shown in the previous section is due to the inefficiency of the single-factor benchmark; i.e., whether using a more efficient benchmark mitigates the possible bias in the estimate of the Jensen Measure. The unconditional three-factor model refers to the following equation:

$$
r_{j, t+1}=\alpha_{j}+\beta_{j} r_{m, t+1}+\beta_{j}^{\mathrm{SMB}} \mathrm{SMB}_{t+1}+\beta_{j}^{\mathrm{HML}} \mathrm{HML}_{t+1}+\varepsilon_{j, t+1},
$$

where $\beta, \beta_{j} \mathrm{SMB}, \beta_{\mathrm{j}} \mathrm{HML}$ are the unconditional betas for the market factor, the size factor and the book-to-market ratio, respectively. Alternately, the conditional three-factor model refers to the following equation:

$$
r_{j, t+1}=a_{j}+\left(b_{1 j}+b_{2 j}{ }^{\prime} z_{t}\right) r_{m, t+1}+\left(b_{1 j}^{\mathrm{SMB}}+b_{2 j}^{\mathrm{SMB}} z_{t}\right) \mathrm{SMB}_{t+1}+\left(b_{1 j}^{\mathrm{HML}}+b_{2 j}^{\mathrm{HML}} z_{t}\right) \mathrm{HML}_{t+1}+\varepsilon_{j, t+1},
$$

where $b_{1}, b_{1} \mathrm{SMB}$ and $b_{1} \mathrm{HML}$ are average conditional beta, and $b_{2}, b_{2} \mathrm{SMB}$ and $b_{2} \mathrm{HML}$ are vectors of beta responsive coefficients with respect to the factors. The vector of information variables, $z_{t}$, includes dividend yield, the one-month Gensaki rate, the term spread and the January dummy. The Jensen Measures are intercepts of the equations. In Table 8 the second and the seventh columns still indicate underperformance where the magnitude of Jensen Measures are close to the estimates from the single-factor models. Panel B of Table 8 and 
Figure 3 show the Jensen Measures of individual funds. Although the results are similar between the two models, the conditional model show slightly more significant negative alphas than the unconditional model.15 In sum, the inclusion of size and book-to-market factors do not affect the underperformance of the funds.

Although the underperformance is not explained, the coefficients on the factors provide interesting information about how managers formed their portfolios. The mimicking factor SMB measures the difference in returns between the large and small stock. A positive (negative) coefficient on the SMB factor indicates that the underlying fund is tilted toward smaller (larger) stocks relative to the market index. From Panel A of Table 8, the SMB slopes for the eight mutual fund portfolios are all negative and the t-statistics exceed 2, except for the ew800, vw190 and ew190 for the unconditional model. For the conditional model, the coefficients are all significant. For the individual funds we find that about one third of the estimates is significantly negative among the 64 funds, and most of them both negative and significant for the 13 well-diversified equity funds.

The mimicking factor HML measures the difference in returns between the high and low $\mathrm{BE} / \mathrm{ME}$ ratio stocks. Again, a negative coefficient on the HML factor indicates that the underlying fund is tilted toward low $\mathrm{BE} / \mathrm{ME}$ ratio stocks relative to the market index. The slopes of the HML factor are all negative for the aggregate portfolios. Although the coefficients are not significant for the 800 portfolios with the unconditional model, they are all significant with the conditional model. For the 64 individual funds, half of them have negative slopes, most of which are not significant for the unconditional model. However, for the conditional model, most of them are negative and half of them are significant. In particular, for the 13 welldiversified equity funds, all of them have negative signs and most of them are statistically significant.

We can conclude that for most of the Japanese mutual funds, the average conditional betas for the SML factor and the HML factor are negative. In other words, the Japanese mutual fund managers tilt towards stocks with large market capitalization and low BE/ME ratios, or large 
and glamour stocks. However, our results show such strategies are not the source of underperformance. 16 In a recent paper, Lakonishok, Shleifer and Vishny (1994) show that investment strategies that buy out-of-favor or value stocks (i.e., those with high book-to-market ratio for example) have outperformed glamour strategies over the 1968-1989 period in the US. They conjecture that the results can be best explained by the preference of both institutional and individual investors for glamour stocks and by their avoidance of value stocks. Particularly institutions might prefer glamour stocks because they appear to be prudent to investors. The results for the Japanese mutual funds are consistent with this conjecture. In addition to this, managers of open-type mutual funds may tend to hold more liquid glamour stocks rather than invest in small and less liquid ones since the funds are exposed to repurchases from the investors. ${ }^{17}$

\subsection{Timing and selectivity}

Timing refers to manager's ability to tilt his portfolio to a greater portion of the market portfolio when market return is higher and vice versa. Treynor and Mazuy (1966) captures such nonlinear relation by a squared term of the return on the market portfolio. Ferson and Schadt (1994) extend the analysis to a conditional setting. Our results (not reported) show negative timing coefficients that are statistically significant for the single index models, both unconditional and conditional. As a result, Jensen's alphas shift in a positive direction, for examples, by $0.175 \%$ per month (2.1\% p.a.) for the vw800 portfolio, and $0.207 \%$ ( $2.5 \%$ p.a.) for the ew800 portfolio, relatively to the alphas of the model without the timing coefficient. Therefore it seems as if part of negative alphas are explained by negative timings.

To assess the validity of the model, we apply the model to the 36 passive portfolios. We find that most of the timing coefficients are negative; particularly portfolios with large and low book-to-market stocks tend to have significant coefficients while the others do not. The alphas of these passive portfolios becomes uniformly higher, say by $0.2 \%$ to $0.3 \%$ per month, compared to those of the models without the timing coefficient. Therefore we cannot conclude 
that the mutual funds' significant timing coefficients and less negative alphas are due to negative timing. Instead, this result may be due to the fact that funds hold large and low bookto-market stocks. Similar results holds for the conditional model as well.18 As pointed out by Admati, Bhattacharya, Pfleiderer, and Ross (1986), it is difficult to separate timing from selective activities. Further, it is possible to construct portfolios that show artificial timing ability when no true timing exists. In practice, investing in options will generate spurious timing, and in less-option-like securities negative timing. For example, a portfolio of lower leveraged firms, which is less option-like in nature, may show negative timing; see Korajczyk and Jagannathan (1986) and Glosten and Jagannathan (1994) for a detailed discussion.

\section{The Dilution Effect of Fund Inflows}

To explain the dilution effect, we first show how capital gain tax is determined for open-type mutual funds. ${ }^{19}$ When an investor sells an existing share of funds, the after-tax price $(P)$ is net asset value (NAV) minus capital gain tax; $P=N A V$-Tax. (Note that the mutual fund returns that we used are calculated from $N A V$.) In the case of open-type mutual funds, the capital gain of a fund is defined by the government as the difference between the current NAV and the historical average of the after-tax price $(P)$ since the start of the fund; i.e., the capital gain is $\operatorname{Max}[N A V-\bar{P}$,

0] where $\bar{P}$ is the average price since the fund's inception, or the average of past $P_{\mathrm{s} .}{ }^{20}$ The government is able to collect taxes without keeping track of individual transactions of investors as long as the capital gain is defined in this manner. Thus, the capital gain of an open-type mutual fund can be calculated for each fund at each point in time, not for each investor transactions.

The NAV per share may be diluted when a new investor buys shares of an existing fund. Dilution occurs when the price investor pays for a share is less than the existing NAV per share. This is the case for open-type funds because a new investor is only required to pay the after-tax NAV (i.e., P), not NAV. Only when there is no capital gain is the after-tax price equal to the NAV per share. Thus when there is capital gain, fund inflow causes the dilution. In the 
case of an outflow, the fund pays out NAV to an investor so that the NAV per share remains the same after the transaction.

The dilution effect can be formulated as follows: Let $n$ be the number of existing mutual fund shares, $a$ the number of newly issued shares, and $d$ the number of repurchased shares by the fund. The value of NAV after the transactions is denoted by a prime, and the after-tax value by $P$ as defined above. When an investor withdraws money out of the fund, the fund pays out the NAV and the investor pays the capital gain tax, if any, from the proceeds, while the new investors pay in only $P$. Therefore we have: $N A V^{\prime}=(n N A V+a P-d N A V) /(n+a-d)=N A V-$ $\alpha \operatorname{Tax}$ where $\alpha=a /(n+a-d)$. If the return on the managed portfolio is $r$ during the period, then we have: $N A V^{\prime}=N A V(1+r)-\alpha \operatorname{Tax}$ where the last term shows the dilution effect. The capital gain tax is calculated using the following formula: $\operatorname{Tax}=(0.2) \operatorname{Max}[N A V(1+r)-\bar{P}, 0]$ where the tax rate is $20 \%$. A single period expected return of the NAV, $\mathrm{E}\left(N A V^{\prime}\right) / N A V-1$, is

$$
\mathrm{E}(r)-(0.2) \mathrm{E}(\alpha \operatorname{Max}[(1+r)-\bar{P} / N A V, 0]),
$$

where $\mathbf{E}$ is the expectation operator. Given the expected performance of the managed portfolio, $\mathbf{E}(r)$, the expected dilution effect is larger if (1) the rate of future inflow of funds $(\alpha)$ is larger and (2) current $\bar{P} / N A V$ is lower. The dilution effect is not an effect that lasts for only a single period, but extends into subsequent periods. In the above example above, the current transaction price of the investor, $P$, is equal to NAV'-(0.2)Tax. In a transaction, inflow or outflow, in the following period, this price is incorporated in the average transaction price, $\bar{P}$. The ratio between this new average transaction price and the NAV in the next period is used to determine the capital gain in the next transaction. Due to this multi-period effect, the dilution effect is larger if (3) the fund is older. The third effect is true since the movement of $\bar{P}$ becomes more smooth and less responsive to the current movement of the NAV as the fund becomes older. Therefore there is higher probability that future NAV is larger than future $\bar{P}$, thus higher probability of dilution.

Since information on $\alpha$ and $\bar{P}$ for individual funds are not available, we conduct a bootstrap experiment using the actual distribution of the single factor benchmark index. 
Although the fund inflow rate is a stochastic variable, we treat it as a non-stochastic parameter in the simulation. We provide results for different inflow rates. We assume that a fund manager invests in an index portfolio which is equal to the single factor benchmark that we used in the previous sections. Thus the portfolio returns are drawn from the distribution of the benchmark returns from January 1981 to December 1992. The experiment is repeated one thousand times each, using various sets of parameters. Table 9 Panel A shows the mean and standard deviation of the dilution effect from one thousand replications for various sets of parameters. The numbers are in terms of percentages per month. From the same set of experiments, Panel B reports the probability that the dilution effect explains the underperformance of $-0.6 \%$ per month which is a ballpark figure of the underperformance of the aggregate mutual fund portfolios. We have no information about the initial difference between NAV and $\vec{P}$ at the starting point of the simulation (i.e., January 1981). Therefore we present three cases where NAV is higher than $\bar{P}$ by $10 \%$, is at the same level as $\bar{P}$, and is lower than $\bar{P}$ by $10 \%$. We know that the average aggregate inflow rate during the observation period is around $0.1(10 \%)$ per month ${ }^{21}$. However, the aggregate inflow includes new mutual funds that started during the observation period. It is the inflow to an existing fund that is relevant to the dilution effect. Thus the inflow that causes dilution should be smaller than that implied by the aggregate inflow rate. Therefore we also provide results that assume smaller inflow rates. The age of the fund at the beginning of the simulation is set equal to 10 years. For example, among the 64 funds, 28 funds existed in January 1981, and the average age was 13.3 years. The effective age of the index of both 64 and 800 funds should be much younger because many of the funds started operation after 1983. Panel A shows that, with the inflow rate of 0.1 , the average dilution effect is between $.336 \%$ and $.424 \%$ per month. Panel B shows that, at this inflow rate, the dilution effect explains the underperformance with probability zero. But it can explain half of the underperformance $(-3 \%)$ with probability of more than fifty percent. At a smaller, but perhaps more reasonable, inflow rate of 0.05 per month, the average 
dilution effect drops to between $.211 \%$ and $.271 \%$ per month, and the probability that it can explain even half the underperformance drops to less than $30 \%$.

However we must be very careful in interpreting these figures because they are based on hypothetical simulations whose assumptions may differ from the situations of individual funds.22 One piece of information suggests that the dilution effect may be less than these simulation suggests. We compare the returns on the two portfolios, ew64 and ew800, noting the average dilution effect could be much less for the latter after the mid-eighties, because the latter portfolio includes many funds that started after that period and that the dilution effect should be less for these funds. We compare the sub-period return of both ew64 and ew800 funds; where the returns are $8.70 \%$ p.a. and $8.41 \%$ p.a. for $1981-86$, and are $-3.50 \%$ p.a. and $3.76 \%$ p.a. for $1987-92$, respectively. We do not find the ew64 return to be less than the ew800 return.

There is a fund selection strategy that allows investors of open-type funds to take advantage of this institutional setting. An anecdotal example is that an investor can select a fund whose NAV is deep below $\bar{P}$, since the probability of future NAV being less than $\bar{P}$ is higher in this case than otherwise. An investor can benefit from two sources if NAV is less than $\bar{P}$ in the future. First, the NAV directly reflects the performance of managers since there is no dilution effect. Second, an investor need not pay capital gain tax. On the other hand, if an investor buys a share in a fund whose NAV is above $\bar{P}$, he or she benefits by paying less than the existing NAV; thus diluting the fund value. However, this investor is more likely to suffer from future dilution effect and also from paying capital gain tax. Using the same simulations as above, we calculate the difference in returns between a strategy of buying a fund whose NAV is below $\bar{P}$ by $10 \%$, and that of buying a fund whose NAV is above $\bar{P}$ by $10 \%$. The result shows that buying funds whose NAV is below $\bar{P}$ yields on average $0.91 \%$ p.a. more than buying funds whose NAV is above $\vec{P} .23$ 


\section{Conclusions and Implications}

In this paper we investigate the performance of the Japanese open-type equity mutual funds. We find that over the Jan. 1981-Dec. 1992 period, the value-weighted and equal-weighted portfolios of the 800 mutual funds run by the nine management companies underperform the single-index benchmark by approximately $7.0 \%$ and $6.0 \%$, respectively. The subset of funds that invest mainly in domestic equity performed even worse. The poor performance was pervasive among the different companies examined, and found in the bull as well as the bear markets.

Our results are robust to the methodology used, as well as the benchmark portfolios used. We consider the possibility that managers tilted their portfolios towards large and glamour firms relative to the single market index, thus we may get underperformance because of using the wrong benchmarks. While we find indeed fund managers tilt towards stocks that have larger market capitalization and low BE/ME ratios, or large and glamour stocks, the funds still underperform by the same magnitude as before, relative to portfolios that passively follow the strategy of buying large and glamour stocks.

We finally are left with the explanation related to institutional features of the mutual fund industry: the excessive turnover, transaction expenses, or the dilution effect from fund inflows on the NAV due to the share prices that is based on the after-tax value. That the compensation of the fund manager is usually not directly linked to the funds' performances and that, on the aggregate, the funds have higher turnover than the market lend some credibility to this. We find, based on bootstrap experiments, that the dilution effect may, under a set of assumptions that yield the maximum effect, explain 3\% p.a. of the underperformance with a probability of fifty percent. However, a comparison between the performance of funds that existed from the beginning of our sample period and those that started later shows that there is not significant difference between their performance, which suggests that the dilution effect may not be serious. Without direct data on turnover, fund composition, and fund inflow, the dilution explanation is at best a conjecture. ${ }^{24}$ The results reported in this paper have raised some 
serious questions concerning the performance of Japanese mutual funds that need to be addressed in future research. 
1 The so-called open-type mutual funds are similar to open-end funds in that new principal can be added to the fund and that investors can cancel their investments by withdrawing the principal. On the other hand, no new principal can be added to the unit-type mutual funds. In contrast to the closed-end funds, unit-type funds are not traded and the investors liquidate their investments by withdrawing the principal.

2 As of May 1994, there are 11 trust companies and one commercial bank that are engaged in the trust function.

3 The Ministry of Finance has licensed non-Japanese affiliated companies to operate mutual fund companies after October 1990, and has licensed Japanese bank-affiliated companies to do the same after October 1993. As of May 1994, the 16 management companies affiliated with domestic brokerage houses include Nomura, Nikko, Yamaichi, Daiwa, Taiyo, Shin-Wako, Sanyo, Asahi, Japan, Daiichi, Kokusai, Cosmo, Tokyo, Universal, Taiheiyo and Toyo. The bank-affiliated management companies include SBIM, Sakura, Sanwa, Nochu and Fuji, and the foreign-affiliated management companies are Warburg, Jardine Fleming, Invesco, Schroder and Credit Suisse.

4 Typically the upper limit of stock investment is 30\% for so called convertible bond open type funds.

5 Source: Flow of Funds Account, The Bank of Japan.

$60.715 \%=1.1 \times\{0.1+(0.1+0.45)\}, 1.320 \%=1.1 \times(0.375+(0.375+0.45)\}$. The securities transfer tax rate for equity has been changed as follows: $0.3 \%$ until $3 / 1978,0.45 \%$ for $4 / 1978-12 / 1987,0.55 \%$ for $1 / 1988-3 / 1992$, $0.3 \%$ from 4/1992. Consumption tax $(0.3 \%)$ is levied on brokerage fees effective April 1989. After this date corresponding variable costs are $0.722 \%=1.1 \times\{0.1 \times 1.03+(0.1 \times 1.03+0.45)\} \quad$ and $1.345 \%=1.1 \times(0.375 \times 1.03+(0.375 \times 1.03+0.45)\}$, respectively. 
7 The choice of the sample period is constrained by the facts that various accounting data, market capitalization, and stock returns from the PACAP database are only available until the end of 1992, and that the value-weighted indices for bonds are not available before 1981.

8 Nomura has one fund which undergoes a 1-for-3 split. Yamaichi, Taiyo and Asahi each have one fund which undergoes a 1-for-2 split. Both the net asset value and dividend payment are adjusted when calculating the returns.

9 The well-diversified Japanese stock funds are selected based on the following criteria: (a) No upper limit on stock investment, (b) upper limit on foreign investment and (c) no specialization in particular industry or type of stocks such as low capitalization or growth stocks.

10 The index is a value-weighted average of the Tokyo Stock Market Index (TOPIX) and Daiwa Bond Index from the Daiwa Institute of Research. The aggregate market values of bonds were also obtained from Daiwa. As of the end of December 1992, stocks, government and corporate bonds, and convertible bonds accounted for $60 \%, 30 \%$, and $10 \%$ of the value of the index portfolio, respectively.

11 As of end-1993, stock open-type mutual funds had 9.6\% of their investment in foreign assets.

12 Ferson and Schadt (1994) show that when equation (2) is the true model, equation (1) is estimated as:

$$
\begin{aligned}
& p \lim \left(\beta_{j}\right)=b_{1 j}+b_{2 j}{ }^{\prime} \operatorname{Cov}\left(r_{m}, z r_{m}\right) / \operatorname{Var}\left(r_{m}\right), \\
& p \lim \left(\alpha_{j}\right)=E\left(r_{m}\right)\left(b_{1 j}-p \lim \left(\beta_{j}\right)\right)+\operatorname{cov}\left(r_{m}, b_{2 j} z\right) .
\end{aligned}
$$

In a different context, Chan (1988) and Ball and Kothari (1989) suggest that the correlation between the time-varying beta and risk premium gives rise to a biased estimate of the returns earned by the contrarian investment strategy.

13 For individual funds, the null hypothesis that the information variables are irrelevant can be rejected at the $5 \%$ level for 47 out of the 64 funds.

14 We reject the null hypothesis that conditional information is irrelevant for the 30 portfolios. 
15 We also calculated the PPW measure from the three-factor model. The results are similar to those obtained from the single factor model.

16 In order to form the passive portfolios, accounting information was obtained from the PACAP Japanese tape which has a forward looking bias; i.e., the delisted firms are excluded from the data whenever the tape is newly compiled. See Chan, Hamao and Lakonishok (1991) for similar comments on Japanese data. The observation period for this study is twelve years from January 1981 to December 1992 and 53 companies were delisted during the period among 1,412 companies in 1981 and 1,651 in 1992. Majority of these companies were delisted either due to mergers and/or to financial distress. Since the number of delisted companies seems to be relatively small, the bias may not be significant for our study.

17 From personal conversation with those in the management companies.

18 We also considered the timing ability using the Merton-Henriksson(1981) model, which models the manager's timing behavior as creating an option-like payoff. Tests involving the passive portfolios show spurious timing ability with this model, thus we did not carry out the analysis of this model on the mutual fund sample.

19 The authors particularly thank Katsuhide Hatanaka and Osamu Shigeta for having drawn our attention to this fact.

20 Capital loss is not recognized in this tax rule.

21 Source: The Investment Trusts Association, Tokyo. From personal interviews with some management firms, we find that the inflow rate of 0.1 is not an unreasonable number for particular months, but it may be too large for the average of the whole period.

22 If more funds flow into funds that have higher performance, the dilution effect would be emphasized.

23 The simulation assumes fund inflow rate of 0.1 per month and a holding period of 10 years. This number is from one of the bootstrap experiments that we conducted above. We also generated the distributions of the rate of return of the traded price, $P$, to assess the impact of 
dilution effect on investors. We find in general that the average return for the investors becomes lower as much as the dilution effect. However, the standard deviations of the returns of $P$ become smaller than those of the NAV returns.

24 Elton, Gruber, Das, and Hlavka (1993) find that funds with higher fees and turnover underperform those with lower fees and turnover for the US. 


\section{References}

Admati, Anat R. and Stephen A. Ross, 1985, "Measuring Investment Performances in a Rational Expectation Model," Journal of Business, 55, 1-26

Admati, Anat R., Sudipto Bhattacharya, Stephen A. Ross and Paul Pfleiderer, 1986, "On Timing and Selectivity," Journal of Finance, 41, 715-731.

Ball, Ray and S. P. Kothari, 1989, "Nonstationary Expected Returns: Implications for Tests of Market Efficiency and Serial Correlation in Returns," Journal of Financial Economics, 25, 51-74.

Brown, S. J., William N. Goetzmann, R. G. Ibbotson and Stephen A. Ross, 1992, "Survivorship Bias in Performance Studies," Review of Financial Studies, 5, 553-580.

Campbell, John Y. and Yasushi Hamao, 1992, "Predictable Stock Returns in the United States and Japan: A Study of Long-term Capital Market Integration," Journal of Finance, 47, 43-69.

Chan, K. C., 1988, "On the Contrarian Investment Strategy," Journal of Business, 61, 147164.

Chan, Louis K. C., Yasushi Hamao and Josef Lakonishok, 1991, "Fundamentals and Stock Returns in Japan," Journal of Finance, 46, 1739-1789.

Dybvig, Philip H. and Stephen A. Ross, 1985, "Differential Information and Performance Measure Using a Security Market Line," Journal of Finance, 40, 383-399.

Elton, Edwin J., Martin J. Gruber, Sanjiv Das, and Matthew Hlavka, 1993, "Efficiency with Costly Information: A Reinterpretation of Evidence from Managed Portfolios," The Review of Financial Studies, 6, 1-22.

Fama, Eugene F. and Kenneth R. French, 1992, "The Cross-Section of Expected Stock Returns," Journal of Finance, 47, 427-465.

1993, "Common Risk Factors in the Returns on Stocks and Bonds," Journal of Financial Economics, 33, 3-56.

Ferson, Wayne E. and Rudi W. Schadt, 1994, "Measuring Fund Strategy and Performance in Changing Economic Conditions," working paper, University of Chicago and University of Washington at Seattle.

Glosten, Lawrence and Ravi Jagannathan, 1994, "A Contingent Claims Approach to Performance Evaluation," Journal of Empirical Finance, 1, 133-166.

Grinblatt, Mark and Sheridan Titman, 1989a, "Mutual Fund Performance: An Analysis of Quarterly Portfolio Holdings," Journal of Business, 62, 393-416. 
1989b, "Portfolio Performance Evaluation: Old Issues and New Insights," Review of Financial Studies, 2, 393-421.

1993, "A Study of Monthly Mutual Fund Returns and Performance Evaluation Techniques," working paper, UCLA.

Henriksson, Roy D., 1984, "Market Timing and Mutual Fund Performance: An Empirical Investigation," Journal of Business, 57, 73-96.

The Investment Trusts Association, Investment Trusts in Japan: 1994, Tokyo, Japan.

Jagannathan, Ravi and Robert A. Korajczyk, 1986, " Assessing the Market Timing Performance of Managed Portfolios," Journal of Business, 59, 217-236.

"Japanese Investment Trusts: Punting in the Dark," Economist, January 22, 1994, 78-79.

Jensen, Michael C., 1968, "The Performance of the Mutual Funds in the Period 19451964," Journal of Finance, 23, 389-416.

1969, "Risk, the Pricing of Capital Assets, and the Evaluation of Investment Portfolios," Journal of Business, 42, 167-247.

1972, "Optimal Utilization of Market Forecasts and the Evaluation of Investment Portfolio Performance," in Giorgio P. Szego and Karl Shell, eds.: Mathematical Methods in Investment and Finance, North Holland, Amsterdam.

Lakonishok, Josef, Andrei Shleifer and Robert W. Vishny, 1994, "Contrarian Investment, Extrapolation, and Risk," working paper, University of Illinois-Champaign and University of Chicago.

Lehmann, Bruce N. and David M. Modest, 1987, "Mutual Fund Performance Evaluation: A Comparison of Benchmarks and Benchmark Comparisons," Journal of Finance, 42, 233-265.

Merton, Robert C. and Roy D. Henriksson, 1981, "On Market Timing and Investment Performance II : Statistical Procedures for Evaluating Forecasting Skills," Journal of Finance, 54, 513-534.

Treynor, Jack and Kay Mazuy, 1966, "Can Mutual Funds Outguess the Market?" Harvard Business Review, 44, 131-136. 


\section{Table 1 An overview of Japanese mutual fund performance}

The numbers in the table are in annualized monthly returns. The Sharpe Measure is a ratio of excess return and the standard deviation. The value- and equalweighted portfolio of 800 funds, vw800 and ew800, represent all the funds managed by nine investment management companies: Nomura, Nikko, Yamaichi, Daiwa, Taiyo, Shin-Wako, Sanyo, Asahi, and Japan. The value- and equal-weighted portfolios of 64 funds, vw64 and ew64, represent a sub-sample of the 800 funds that are selected based on the criteria that they have more than 97 observations during the observation period. Well-diversified Japanese equity funds invest all or mostly in Japanese stocks with no specialization in particular industry or type of stocks such as growth or low capitalization stocks. The 190 and 13 funds are subsets of the 800 and 64 funds, respectively. The value-weighted index is a portfolio of stocks from both sections of the TSE, all government and corporate bonds with longer than one-year maturity, and convertible bonds. The buy-and-hold index is an equally weighted portfolio that consists of the 30 largest stocks on the TSE as of December 1980. Bond index consists of all government and corporate bonds with a longer than one-year maturity, and convertible bonds. The maturity of the Gensaki rate is one month.

\begin{tabular}{|c|c|c|c|c|c|c|c|c|c|c|c|c|}
\hline \multirow[t]{2}{*}{ Periods } & \multicolumn{4}{|c|}{ Jan. 1981 - Dec. 1992} & \multicolumn{4}{|c|}{ Jan. 1981 - Dec. 1989} & \multicolumn{4}{|c|}{ Jan. 1990 - Dec. 1992} \\
\hline & $\begin{array}{l}\text { Mean } \\
\text { return } \\
\text { (\%p.a.) }\end{array}$ & $\begin{array}{l}\text { Standard } \\
\text { deviation }\end{array}$ & $\begin{array}{l}\text { Mean } \\
\text { excess } \\
\text { return }\end{array}$ & $\begin{array}{l}\text { Sharpe } \\
\text { measure }\end{array}$ & $\begin{array}{l}\text { Mean } \\
\text { return } \\
\text { (\%p.a.) }\end{array}$ & $\begin{array}{l}\text { Standard } \\
\text { deviation }\end{array}$ & $\begin{array}{l}\text { Mean } \\
\text { excess } \\
\text { return } \\
\end{array}$ & $\begin{array}{l}\text { Sharpe } \\
\text { measure }\end{array}$ & $\begin{array}{l}\text { Mean } \\
\text { return } \\
\text { (\% p.a.) }\end{array}$ & $\begin{array}{l}\text { Standard } \\
\text { deviation }\end{array}$ & $\begin{array}{l}\text { Mean } \\
\text { excess } \\
\text { return }\end{array}$ & $\begin{array}{l}\text { Sharpe } \\
\text { measure }\end{array}$ \\
\hline \multicolumn{13}{|l|}{ (All category) } \\
\hline vw800 & 1.73 & 14.67 & -3.95 & -0.269 & 8.59 & 11.39 & 3.03 & 0.266 & -18.84 & 20.84 & -24.88 & -1.194 \\
\hline ew800 & 2.41 & 13.15 & -3.27 & -0.249 & 8.40 & 10.33 & 2.84 & 0.274 & -15.55 & 18.53 & -21.60 & -1.166 \\
\hline vw64 & 1.23 & 14.39 & -4.45 & -0.309 & 7.67 & 12.08 & 2.11 & 0.175 & -18.10 & 18.89 & -24.15 & -1.278 \\
\hline ew64 & 2.13 & 13.51 & -3.55 & -0.263 & 7.97 & 11.42 & 2.41 & 0.211 & -15.39 & 17.65 & -21.44 & -1.223 \\
\hline \multicolumn{13}{|c|}{ (Well-diversified Japanese equity funds) } \\
\hline vw190 & -0.127 & 17.73 & -5.81 & -0.328 & 8.24 & 13.20 & 2.68 & 0.203 & -25.22 & 26.07 & -31.26 & -1.199 \\
\hline ew190 & 1.26 & 16.87 & -4.43 & -0.262 & 9.50 & 12.77 & 3.94 & 0.308 & -23.47 & 24.39 & -29.51 & -1.210 \\
\hline vw13 & -2.09 & 17.70 & -7.77 & -0.439 & 5.62 & 14.04 & 0.06 & 0.004 & -25.20 & 24.83 & -31.25 & -1.259 \\
\hline ew13 & 0.55 & 16.41 & -5.13 & -0.313 & 8.11 & 13.48 & 2.54 & 0.189 & -22.10 & 22.03 & -28.15 & -1.278 \\
\hline Value-weighted index & 8.91 & 13.77 & 3.22 & 0.234 & 16.19 & 10.03 & 10.62 & 1.059 & -12.93 & 20.32 & -18.97 & -0.934 \\
\hline Buy-and-hold 30 & 14.85 & 21.98 & 9.17 & 0.417 & 26.46 & 19.07 & 20.89 & 1.095 & -19.95 & 26.90 & -26.00 & -0.966 \\
\hline Bond index & 7.78 & 3.89 & 2.09 & 0.538 & 8.19 & 3.50 & 2.63 & 0.753 & 6.52 & 4.93 & 0.474 & 0.096 \\
\hline Gensaki rate & 5.68 & 0.38 & N/A & N/A & 5.56 & 0.36 & N/A & N/A & 6.04 & 0.420 & N/A & N/A \\
\hline
\end{tabular}


Table 2 Summary statistics of selected Japanese mutual funds

\begin{tabular}{|c|c|c|c|c|c|c|c|c|}
\hline \multicolumn{2}{|r|}{ Nomura Securities Investment Trust Management } & Begin & End & Obs & Mean & Std. Dev & Max & Min \\
\hline & All funds (155) & 8101 & 9212 & 144 & 0.273 & 3.659 & 10.64 & -14.19 \\
\hline & Well-diversified Japanese equity funds (54) & 8101 & 9212 & 144 & 0.283 & 4.551 & 13.80 & -18.39 \\
\hline 1 & No. 1 open* & 8101 & 8909 & 105 & 0.852 & 3.848 & 11.74 & -15.13 \\
\hline 2 & No. 2 open $*$ & 8101 & 8901 & 97 & 0.941 & 3.880 & 16.95 & -11.75 \\
\hline 3 & New large stock fund & 8101 & 9110 & 130 & 0.690 & 4.295 & 14.91 & -16.54 \\
\hline 4 & Stock accumulation fund $*$ & 8101 & 9212 & 144 & 0.445 & 5.401 & 16.32 & -18.20 \\
\hline 5 & Foreign natural resources stock fund & 8101 & 9212 & 144 & 0.296 & 4.246 & 10.01 & -26.79 \\
\hline 6 & CB open & 8401 & 9212 & 108 & 0.451 & 4.017 & 13.61 & -13.80 \\
\hline 7 & Rainbow fund - Information electronics fund & 8403 & 9212 & 106 & -0.334 & 6.461 & 16.70 & -20.02 \\
\hline 8 & Rainbow fund - Health care fund & 8403 & 9212 & 106 & 0.364 & 4.893 & 14.77 & -12.23 \\
\hline 9 & Rainbow fund - Cyclical industry fund & 8403 & 9212 & 106 & 0.106 & 5.595 & 14.53 & -16.48 \\
\hline 10 & Rainbow fund - Mechatronics fund & 8403 & 9212 & 106 & -0.251 & 5.411 & 14.11 & -16.31 \\
\hline 11 & Rainbow fund - Public utility stock fund & 8403 & 9212 & 106 & 0.326 & 5.421 & 15.85 & -15.14 \\
\hline 12 & Rainbow fund - Excellent fund & 8403 & 9212 & 106 & 0.185 & 3.633 & 11.86 & -12.95 \\
\hline \multicolumn{9}{|c|}{ Nikko Securities Investment Trust \& Management } \\
\hline & All funds (118) & 8101 & 9212 & 144 & 0.124 & 4.411 & 12.10 & -16.30 \\
\hline & Well-diversified Japanese equity funds (33) & 8101 & 9212 & 144 & 0.017 & 5.857 & 15.11 & -19.23 \\
\hline 13 & No. 1 open* & 8101 & 9212 & 144 & -0.109 & 5.851 & 14.59 & -21.26 \\
\hline 14 & New large stock fund & 8101 & 9212 & 144 & 0.127 & 4.972 & 17.91 & -15.23 \\
\hline 15 & Global growth fund & 8101 & 9212 & 144 & 0.096 & 4.521 & 10.12 & -13.92 \\
\hline 16 & Capital open* & 8101 & 9212 & 144 & -0.248 & 5.888 & 13.62 & -21.66 \\
\hline 17 & $\mathrm{CB}$ fund & 8312 & 9212 & 109 & 0.332 & 3.487 & 9.23 & -13.64 \\
\hline 18 & My select - New media portfolio & 8404 & 9212 & 105 & -0.619 & 7.159 & 15.52 & -27.10 \\
\hline 19 & My select - Mechatronics portfolio & 8404 & 9212 & 105 & -0.591 & 6.595 & 17.11 & -21.24 \\
\hline 20 & My select - Health care portfolio & 8404 & 9212 & 105 & 0.177 & 5.272 & 17.00 & -14.95 \\
\hline 21 & My select - New service portfolio & 8404 & 9212 & 105 & -0.078 & 5.002 & 10.87 & -18.12 \\
\hline 22 & My select - Cyclical industry portfolio & 8404 & 9212 & 105 & -0.301 & 5.799 & 15.17 & -24.64 \\
\hline \multicolumn{9}{|c|}{ Yamaichi Investment Trust and Management } \\
\hline & All funds (88) & 8101 & 9212 & 144 & 0.139 & 4.200 & 11.85 & -16.90 \\
\hline & Well-diversified Japanese equity funds (21) & 8101 & 9212 & 144 & 0.010 & 5.242 & 15.43 & -19.70 \\
\hline 23 & No. 1 open* & 8101 & 9212 & 144 & -0.062 & 5.301 & 14.32 & -25.62 \\
\hline 24 & New large stock fund & 8101 & 9212 & 144 & -0.094 & 5.638 & 18.70 & -24.47 \\
\hline 25 & Universal fund & 8101 & 9212 & 144 & 0.338 & 8.815 & 53.74 & -52.32 \\
\hline 26 & New large stock-bond fund & 8101 & 9212 & 144 & 0.313 & 4.826 & 17.37 & -15.61 \\
\hline 27 & $\mathrm{CB}$ open & 8401 & 9212 & 108 & 0.188 & 3.927 & 10.47 & -14.24 \\
\hline 28 & Select fund - Information electronics portfolio & 8404 & 9212 & 105 & -0.472 & 6.396 & 12.52 & -26.36 \\
\hline 29 & Select fund - Life science portfolio & 8404 & 9212 & 105 & 0.027 & 5.303 & 16.27 & -15.28 \\
\hline 30 & Select fund - New service portfolio & 8404 & 9212 & 105 & -0.113 & 5.288 & 14.08 & -22.18 \\
\hline 31 & Select fund - Resources-energy portfolio & 8404 & 9212 & 105 & -0.364 & 5.522 & 16.57 & -19.63 \\
\hline 32 & Select fund - Cyclical industry portfolio & 8404 & 9212 & 105 & -0.306 & 5.388 & 12.10 & -17.38 \\
\hline \multicolumn{9}{|c|}{ Daiwa Investment Trust and Management } \\
\hline & All funds $(200)$ & 8101 & 9212 & 144 & 0.269 & 3.535 & 9.10 & -14.40 \\
\hline & Well-diversified Japanese equity funds (26) & 8101 & 9212 & 144 & 0.037 & 4.994 & 14.24 & -17.26 \\
\hline 33 & No. 1 open* & 8101 & 9212 & 144 & -0.112 & 5.097 & 13.95 & -15.57 \\
\hline 34 & No. 2 open* & 8101 & 9212 & 144 & -0.090 & 5.397 & 12.15 & -15.26 \\
\hline 35 & Large stock fund & 8101 & 9212 & 144 & -0.051 & 5.280 & 16.32 & -16.16 \\
\hline 36 & Foreign stock fund & 8101 & 9212 & 144 & 0.115 & 4.638 & 11.55 & -25.64 \\
\hline 37 & CB open & 8411 & 9212 & 98 & 0.762 & 3.550 & 12.57 & -16.89 \\
\hline 38 & Super select fund-Electronics portfolio & 8401 & 9212 & 108 & -0.739 & 6.673 & 15.68 & -21.31 \\
\hline 39 & Super select fund-Life science portfolio & 8401 & 9212 & 108 & -0.075 & 5.464 & 18.79 & -17.05 \\
\hline 40 & Super select fund-Resources-energy portfolio & 8401 & 9212 & 108 & -0.067 & 5.153 & 15.13 & -19.13 \\
\hline 41 & Super select fund-Cyclical industry portfolio & 8401 & 9212 & 108 & -0.014 & 5.549 & 14.41 & -22.31 \\
\hline 42 & Super select fund - Leading stock portfolio & 8401 & 9212 & 108 & -0.034 & 4.895 & 12.83 & -17.03 \\
\hline
\end{tabular}


Table 2 (Continued)

\begin{tabular}{|c|c|c|c|c|c|c|c|c|}
\hline \multicolumn{2}{|r|}{ The Taiyo Investment Trust Management } & Begin & End & Obs & Mean & Std. Err. & $\operatorname{Max}$ & Min \\
\hline \multicolumn{2}{|r|}{ All funds (58) } & 8101 & 9212 & 144 & 0.152 & 4.101 & 13.84 & -17.76 \\
\hline \multicolumn{2}{|r|}{ Well-diversified Japanese equity funds (12) } & 8101 & 9212 & 144 & -0.021 & 5.190 & 16.65 & -20.32 \\
\hline 43 & Balance open & 8101 & 9212 & 144 & 0.284 & 2.828 & 9.67 & -10.64 \\
\hline 44 & Capital open* & 8101 & 9212 & 144 & -0.077 & 5.237 & 17.21 & -23.28 \\
\hline 45 & Hi select fund - Electronics portfolio & 8412 & 9212 & 97 & -0.470 & 6.944 & 15.58 & -25.71 \\
\hline 46 & Hi select fund - Life science portfolio & 8412 & 9212 & 97 & -0.093 & 5.928 & 23.41 & -15.00 \\
\hline 47 & Hi select fund - New industrial materials portfolio & 8412 & 9212 & 97 & -0.172 & 6.703 & 21.09 & -25.04 \\
\hline 48 & Hi select fund - New business portfolio & 8412 & 9212 & 97 & 0.032 & 6.070 & 19.83 & -23.17 \\
\hline 49 & Hi select fund - Cyclical industry/hidden asset & 8412 & 9212 & 97 & 0.223 & 6.487 & 19.61 & -23.21 \\
\hline \multicolumn{9}{|c|}{ Shin-Wako Investment Trust Management } \\
\hline & All funds (47) & 8101 & 9212 & 144 & 0.190 & 3.848 & 11.81 & -15.41 \\
\hline & Well-diversified Japanese equity funds (13) & 8101 & 9212 & 144 & -0.106 & 5.055 & 12.76 & -21.18 \\
\hline 50 & Balance fund & 8101 & 9212 & 144 & 0.527 & 2.032 & 6.85 & -6.73 \\
\hline 51 & International fund* & 8101 & 9212 & 144 & 0.126 & 4.173 & 12.18 & -21.18 \\
\hline 52 & CB open & 8403 & 9212 & 106 & 0.615 & 1.989 & 6.16 & -7.12 \\
\hline \multicolumn{9}{|c|}{ Sanyo Investment Trust Management } \\
\hline & All funds (39) & 8101 & 9212 & 144 & 0.202 & 4.136 & 12.13 & -15.54 \\
\hline & Well-diversified Japanese equity funds (13) & 8101 & 9212 & 144 & 0.250 & 5.032 & 13.05 & -16.55 \\
\hline 53 & Open* & 8101 & 9212 & 144 & 0.080 & 5.002 & 11.76 & -20.40 \\
\hline \multicolumn{9}{|c|}{ The Asahi Investment Trust Management } \\
\hline & All funds (59) & 8101 & 9212 & 144 & 0.201 & 3.790 & 12.27 & -14.93 \\
\hline & Well-diversified Japanese equity funds (12) & 8101 & 9212 & 144 & 0.270 & 5.140 & 14.82 & -17.59 \\
\hline 54 & Balance fund & 8101 & 9202 & 134 & 0.737 & 2.243 & 7.18 & -9.16 \\
\hline 55 & Large stock fund & 8101 & 9010 & 118 & 0.645 & 3.025 & 10.02 & -8.93 \\
\hline 56 & Pacific fund & 8101 & 9212 & 144 & -0.211 & 4.340 & 8.63 & -25.90 \\
\hline 57 & Stock open* & 8101 & 9212 & 144 & 0.306 & 4.677 & 15.27 & -13.67 \\
\hline 58 & CB open & 8312 & 9212 & 109 & 0.540 & 3.509 & 14.90 & -10.87 \\
\hline 59 & New select fund - Information portfolio & 8403 & 9212 & 106 & -0.217 & 6.032 & 13.18 & -22.58 \\
\hline 60 & New select fund - New industrial materials portfolio & 8403 & 9212 & 106 & -0.060 & 4.810 & 13.15 & -15.36 \\
\hline 61 & New select fund - Life science portfolio & 8403 & 9212 & 106 & 0.196 & 4.524 & 14.86 & -13.36 \\
\hline 62 & New select fund - Hidden asset portfolio & 8403 & 9212 & 106 & 0.295 & 5.464 & 16.61 & -17.87 \\
\hline \multicolumn{9}{|c|}{ Japan Investment Trust Management } \\
\hline & All funds (36) & 8101 & 9212 & 144 & 0.019 & 4.532 & 12.95 & -17.77 \\
\hline & Well-diversified Japanese equity funds (7) & 8101 & 9212 & 144 & -0.098 & 6.216 & 17.40 & -19.68 \\
\hline 63 & Balance fund & 8101 & 9212 & 144 & 0.354 & 2.578 & 6.75 & -9.57 \\
\hline 64 & Nihon open* & 8101 & 9212 & 144 & -0.091 & 5.929 & 17.40 & -21.60 \\
\hline \multicolumn{9}{|c|}{ Aggregate Mutual Fund Portfolios } \\
\hline 65 & vw800 (All category) & 8101 & 9212 & 144 & 0.144 & 4.236 & 12.54 & -15.88 \\
\hline 66 & ew800 & 8101 & 9212 & 144 & 0.201 & 3.795 & 10.83 & -14.78 \\
\hline 67 & vw64 & 8101 & 9212 & 144 & 0.102 & 4.153 & 10.99 & -15.08 \\
\hline 68 & ew64 & 8101 & 9212 & 144 & 0.178 & 3.899 & 10.22 & -14.76 \\
\hline 69 & vw190 (Well-diversified Japanese equity funds) & 8101 & 9212 & 144 & -0.011 & 5.118 & 15.21 & -18.93 \\
\hline 70 & ew190 & 8101 & 9212 & 144 & 0.105 & 4.870 & 14.40 & -18.58 \\
\hline 71 & vw13 & 8101 & 9212 & 144 & -0.174 & 5.109 & 14.18 & -18.89 \\
\hline 72 & ew13 & 8101 & 9212 & 144 & 0.046 & 4.736 & 13.01 & -18.84 \\
\hline
\end{tabular}




\section{(Notes for Table 2)}

The 64 individual funds are selected based on the criteria that they have more than 97 observations during the Jan. 1981 - Dec. 1992 period. The portfolios of funds for each management company are equally weighted of all the funds that existed during the observation period. Among all the funds, well-diversified Japanese equity funds indicated by asterisk $\left(^{*}\right)$ are those that invest all or mostly in Japanese stocks with no specialization in particular industry or type of stocks such as growth or low capitalization stocks. The figures in the parentheses show the number of funds in the portfolio. The indices vw800 and ew800 refer to the value- and equal-weighted portfolios for all 800 mutual funds managed by the nine management companies. Portfolios, vw64 and ew64, refer to the value- and equal-weighted portfolios for the 64 funds that had more than 97 observations during the observation period. The well diversified 190 and 13 funds are subsets of 800 and 64 funds, respectively. The returns are in percentage rates per month. The names of individual funds are not necessarily the direct translations of the original Japanese names. 


\section{Table 3 The basic performance measures}

Panel A compares Positive Period Weighting Measure as well as the unconditional and conditional Jensen Measures from the single-index model for the aggregate mutual fund portfolios. Well-diversified Japanese equity funds invest all or mostly in Japanese stocks with no specialization in particular industry or type of stocks such as growth or low capitalization stocks. These 190 and 13 funds are subsets of the 800 and 64 funds, respectively. The value-weighted portfolio of stocks from both sections of the TSE, all government and corporate bonds with a more than one-year maturity, and convertible bonds, is used as the benchmark. The information variables include the dividend yield, one month Gensaki rate, the long-short spread and the January dummy. The $\mathrm{R}^{2}$ is adjusted correlation coefficient, and $\mathrm{p}$-value indicates the significance of the information variables. Heteroskedasticity-adjusted t-statistics are in the parenthesis. Asterisks (*) indicate significance at $10 \%$ level. Panel B reports the number of the positive, negative, and significantly negative Jensen Measures for 64 individual funds and the subset of 13 well-diversified Japanese equity funds under various models. The performances are measured in percentage per month.

Period: Jan. 1981 - Dec. 1992

\begin{tabular}{|c|c|c|c|c|c|c|}
\hline \multirow[t]{2}{*}{ Panel A } & \multirow{2}{*}{ PPW } & \multicolumn{2}{|c|}{ Unconditional } & \multicolumn{2}{|c|}{ Conditional } & \multirow[b]{2}{*}{ p-value } \\
\hline & & $\alpha$ & $\mathrm{R}^{2}$ & $\alpha$ & $\mathrm{R}^{2}$ & \\
\hline \multicolumn{7}{|c|}{ (All category) } \\
\hline vw800 & $\begin{array}{l}-0.588^{*} \\
(3.795)\end{array}$ & $\begin{array}{c}-0.587 * \\
(3.833)\end{array}$ & 0.810 & $\begin{array}{c}-0.588^{*} \\
(4.127)\end{array}$ & 0.843 & 0.000 \\
\hline ew800 & $\begin{array}{l}-0.504^{*} \\
(3.494)\end{array}$ & $\begin{array}{c}-0.501 * \\
(3.474)\end{array}$ & 0.795 & $\begin{array}{c}-0.488^{*} \\
(3.754)\end{array}$ & 0.836 & 0.000 \\
\hline vw64 & $\begin{array}{l}-0.613^{*} \\
(3.391)\end{array}$ & $\begin{array}{c}-0.611^{*} \\
(3.408)\end{array}$ & 0.731 & $\begin{array}{c}-0.638^{*} \\
(3.897)\end{array}$ & 0.778 & 0.000 \\
\hline ew64 & $\begin{array}{l}-0.523^{*} \\
(3.048)\end{array}$ & $\begin{array}{l}-0.520^{*} \\
(3.014)\end{array}$ & 0.726 & $\begin{array}{c}-0.522 * \\
(3.287)\end{array}$ & 0.773 & 0.000 \\
\hline \multicolumn{7}{|c|}{ (Well-diversified Japanese equity funds) } \\
\hline vw190 & $\begin{array}{l}-0.797 * \\
(4.230)\end{array}$ & $\begin{array}{c}-0.795^{*} \\
(4.271)\end{array}$ & 0.808 & $\begin{array}{c}-0.795^{*} \\
(4.381)\end{array}$ & 0.830 & 0.002 \\
\hline ew190 & $\begin{array}{l}-0.670^{*} \\
(3.927)\end{array}$ & $\begin{array}{c}-0.668^{*} \\
(3.959)\end{array}$ & 0.826 & $\begin{array}{c}-0.681^{*} \\
(4.240)\end{array}$ & 0.852 & 0.000 \\
\hline vw13 & $\begin{array}{l}-0.940^{*} \\
(4.030)\end{array}$ & $\begin{array}{l}-0.937^{*} \\
(4.052)\end{array}$ & 0.704 & $\begin{array}{c}-0.931 * \\
(4.361)\end{array}$ & 0.750 & 0.000 \\
\hline ew13 & $\begin{array}{l}-0.704^{*} \\
(3.438)\end{array}$ & $\begin{array}{l}-0.701^{*} \\
(3.430)\end{array}$ & 0.734 & $\begin{array}{l}-0.737^{*} \\
(3.925)\end{array}$ & 0.783 & 0.000 \\
\hline Panel B & \multicolumn{6}{|c|}{$\begin{array}{l}\text { The number of positive and negative measures of } 64 \text { individual funds. } \\
\text { [The number of } 13 \text { well-diversifed Japanese equity funds.] }\end{array}$} \\
\hline Positive & $3[0]$ & $3[0]$ & & $4[0]$ & & \\
\hline Negative & $61[13]$ & $61[13]$ & & $60[13]$ & & \\
\hline Sig. at $10 \%$ & $40[12]$ & $41[11]$ & & 35 [12] & & \\
\hline Sig at $5 \%$ & $30[11]$ & $30[11]$ & & $30[11]$ & & \\
\hline
\end{tabular}




\section{Table 4 Betas}

The Panel A reports the estimates for the conditional and unconditional beta for the aggregate mutual fund portfolios from the single-index model. The coefficient $\beta$ (subscript $\mathrm{j}$ omitted) is an unconditional beta from the following regression:

$$
r_{j, t+1}=\alpha_{j}+\beta_{j} r_{m, t+1}+\varepsilon_{j, t+1}
$$

where $r_{j, t+1}$ is the excess return for the $\mathrm{j}$-th mutual fund, $r_{m, t+1}$ is the excess return on the market portfolio. The coefficient $b_{1}$ is the average conditional beta and $b_{2}$ is the vector of beta responsive coefficients from the following model:

$$
r_{j, t+1}=a_{j}+b_{1 j} r_{m, t+1}+b_{2 j}{ }^{\prime}\left(z_{t} r_{m, t+1}\right)+\varepsilon_{j, t+1}
$$

The vector of information variables, $z$, includes dividend yield, one-month Gensaki rate, long-short spread and the January dummy variable. Therefore $b_{2}=\left(b_{\mathrm{div}}, b_{\mathrm{rg}}, b_{\mathrm{sp}}, b_{\mathrm{jdum}}\right)^{\prime}$. Heteroskedasticity-adjusted tstatistics are in the parenthesis. Asterisks (*) indicate significance at $10 \%$ level. Panel B reports the number of positive, significantly positive, negative and significantly negative coefficients for the 64 and its subset of 13 individual funds. The significance level is $10 \%$.

\begin{tabular}{|c|c|c|c|c|c|c|}
\hline Panel A & $\beta$ & $b_{1}$ & $b_{\text {div }}$ & $b_{\mathrm{rg}}$ & $b_{\mathrm{sp}}$ & $b_{\text {idum }}$ \\
\hline \multicolumn{7}{|c|}{ (All category) } \\
\hline \multirow[t]{2}{*}{ vw800 } & $0.958^{*}$ & $1.129^{*}$ & $0.350^{*}$ & $1.026^{*}$ & 1.412 & $-0.352 *$ \\
\hline & $(20.989)$ & $(19.217)$ & $(2.098)$ & $(2.380)$ & $(1.476)$ & $(1.803)$ \\
\hline \multirow[t]{2}{*}{ ew800 } & $0.851^{*}$ & $0.999 *$ & 0.275 & $1.193^{*}$ & 1.631 & $-0.311 *$ \\
\hline & (18.448) & $(16.642)$ & $(1.420)$ & (2.539) & (1.368) & $(2.060)$ \\
\hline \multirow[t]{2}{*}{ vw64 } & $0.893 *$ & $1.122 *$ & $0.501^{*}$ & $0.929^{*}$ & 1.685 & $-0.405^{*}$ \\
\hline & $(16.295)$ & $(16.426)$ & $(2.349)$ & $(1.826)$ & $(1.315)$ & $(1.724)$ \\
\hline \multirow[t]{2}{*}{ ew64 } & $0.835^{*}$ & $1.022 *$ & 0.371 & $1.176^{*}$ & 1.841 & $-0.346^{*}$ \\
\hline & $(15.782)$ & $(12.839)$ & $(1.542)$ & $(2.166)$ & (1.335) & $(2.014)$ \\
\hline \multicolumn{7}{|c|}{ (Well-diversified Japanese equity funds) } \\
\hline \multirow[t]{2}{*}{ vw190 } & $1.156^{*}$ & $1.323^{*}$ & $0.326^{*}$ & $1.031^{*}$ & $1.721^{*}$ & -0.316 \\
\hline & $(23.866)$ & $(16.696)$ & $(1.725)$ & $(2.432)$ & (2.027) & $(1.531)$ \\
\hline \multirow[t]{2}{*}{ ew190 } & $1.113^{*}$ & $1.295 *$ & $0.403 *$ & $1.156^{*}$ & 1.428 & -0.289 \\
\hline & (23.940) & $(17.630)$ & $(2.184)$ & $(2.702)$ & (1.614) & (1.406) \\
\hline \multirow[t]{2}{*}{ vw13 } & $1.077^{*}$ & $1.314 *$ & $0.446^{*}$ & $1.458^{*}$ & $2.541^{*}$ & $-0.480 *$ \\
\hline & (16.141) & (15.363) & $(1.784)$ & $(2.687)$ & $(1.752)$ & $(1.756)$ \\
\hline \multirow[t]{2}{*}{ ew13 } & $1.020^{*}$ & $1.281 *$ & $0.601 *$ & $1.449^{*}$ & 1.945 & -0.342 \\
\hline & (17.151) & $(14.587)$ & $(2.472)$ & $(2.821)$ & $(1.541)$ & $(1.582)$ \\
\hline \multirow[t]{2}{*}{ Panel B: } & \multicolumn{6}{|c|}{$\begin{array}{l}\text { The number of positive and negative measures of } 64 \text { individual funds. } \\
\text { [The number of } 13 \text { well-diversified Japanese equity funds.] }\end{array}$} \\
\hline & $\beta$ & $b_{1}$ & $b_{\mathrm{div}}$ & $b_{\mathrm{rg}}$ & $b_{\mathrm{sp}}$ & $b_{\text {idum }}$ \\
\hline Positive & $64[13]$ & $63[13]$ & $47[13]$ & $53[12]$ & 54 [11] & $1[0]$ \\
\hline Sig. pos. & $62[13]$ & $60[13]$ & $23[6]$ & $27[6]$ & $17[4]$ & $0[0]$ \\
\hline Negative & $0[0]$ & $1[0]$ & $17[0]$ & $11[1]$ & $10[2]$ & $63[13]$ \\
\hline Sig. neg. & $0[0]$ & $0[0]$ & $1[0]$ & $3[0]$ & $0[0]$ & $25[4]$ \\
\hline
\end{tabular}

Period: Jan. 1981 - Dec. 1992 


\section{Table 5 Basic performance measures: Subperiod analysis}

The Positive Period Weighting Measure (PPW) as well as the unconditional and conditional Jensen Measures are calculated from the single-index model for the aggregate mutual fund portfolios. Well-diversified Japanese equity funds invest all or mostly in Japanese stocks with no specialization in particular industry or type of stocks such as growth or low capitalization stocks. These 190 and 13 funds are subsets of the 800 and 64 funds, respectively. The valueweighted portfolio of stocks from both sections of the TSE, all government and corporate bonds with a more than one-year maturity, and convertible bonds, is used as the benchmark. The information variables for the conditional models include the dividend yield, one month Gensaki rate, the long-short spread and the January dummy. The $\mathrm{R}^{2}$ is adjusted correlation coefficient, and the p-values indicate the significance of the information variables. Heteroskedasticityadjusted t-statistics are in the parenthesis. Asterisks $(*)$ indicate significance at $10 \%$ level. The performances are measured in percentage per month.

\begin{tabular}{|c|c|c|c|c|c|c|c|c|c|c|c|c|}
\hline & \multicolumn{6}{|c|}{ Jan. 1981 - Dec. 1989} & \multicolumn{6}{|c|}{ Jan. 1990 - Dec. 1992} \\
\hline & \multicolumn{3}{|c|}{ Unconditional } & \multicolumn{3}{|c|}{ Conditional } & \multicolumn{3}{|c|}{ Unconditional } & \multicolumn{3}{|c|}{ Conditional } \\
\hline & PPW & $\alpha$ & $\mathrm{R}^{2}$ & $\alpha$ & $\mathrm{R}^{2}$ & p-value & PPW & $\alpha$ & $\mathrm{R}^{2}$ & $\alpha$ & $\mathrm{R}^{2}$ & p-value \\
\hline \multicolumn{13}{|c|}{ (All category) } \\
\hline vw800 & $\begin{array}{l}-0.576^{*} \\
(2.768)\end{array}$ & $\begin{array}{c}-0.533^{*} \\
(2.415)\end{array}$ & 0.611 & $\begin{array}{l}-0.435^{*} \\
(2.355)\end{array}$ & 0.705 & 0.000 & $\begin{array}{c}-0.483^{*} \\
(3.007)\end{array}$ & $\begin{array}{c}-0.470^{*} \\
(3.186)\end{array}$ & 0.977 & $\begin{array}{c}-0.599 * \\
(4.283)\end{array}$ & 0.982 & 0.097 \\
\hline ew800 & $\begin{array}{l}-0.515^{*} \\
(2.679)\end{array}$ & $\begin{array}{c}-0.466^{*} \\
(2.119)\end{array}$ & 0.595 & $\begin{array}{l}-0.358^{*} \\
(2.223)\end{array}$ & 0.715 & 0.000 & $\begin{array}{l}-0.399 * \\
(2.374)\end{array}$ & $\begin{array}{l}-0.382^{*} \\
(2.380)\end{array}$ & 0.968 & $\begin{array}{c}-0.516^{*} \\
(3.543)\end{array}$ & 0.974 & 0.169 \\
\hline vw64 & $\begin{array}{l}-0.649 * \\
(2.675)\end{array}$ & $\begin{array}{c}-0.598 * \\
(2.298)\end{array}$ & 0.528 & $\begin{array}{l}-0.474 * \\
(2.265)\end{array}$ & 0.650 & 0.000 & $\begin{array}{l}-0.593^{*} \\
(2.819)\end{array}$ & $\begin{array}{c}-0.578^{*} \\
(3.034)\end{array}$ & 0.952 & $\begin{array}{c}-0.789^{*} \\
(4.344)\end{array}$ & 0.965 & 0.043 \\
\hline ew64 & $\begin{array}{l}-0.593^{*} \\
(2.619)\end{array}$ & $\begin{array}{c}-0.540^{*} \\
(2.096)\end{array}$ & 0.542 & $\begin{array}{l}-0.427^{*} \\
(2.156)\end{array}$ & 0.664 & 0.000 & $\begin{array}{l}-0.483^{*} \\
(2.034)\end{array}$ & $\begin{array}{l}-0.462^{*} \\
(2.174)\end{array}$ & 0.930 & $\begin{array}{c}-0.680^{*} \\
(3.340)\end{array}$ & 0.945 & 0.114 \\
\hline \multicolumn{13}{|c|}{ (Well-diversified Japanese equity funds) } \\
\hline vw190 & $\begin{array}{l}-0.723^{*} \\
(2.924)\end{array}$ & $\begin{array}{c}-0.673^{*} \\
(2.570)\end{array}$ & 0.591 & $\begin{array}{l}-0.553^{*} \\
(2.358)\end{array}$ & 0.658 & 0.001 & $\begin{array}{l}-0.620^{*} \\
(2.902)\end{array}$ & $\begin{array}{c}-0.604 * \\
(2.893)\end{array}$ & 0.974 & $\begin{array}{c}-0.710^{*} \\
(3.840)\end{array}$ & 0.983 & 0.010 \\
\hline ew190 & $\begin{array}{l}-0.613^{*} \\
(2.688)\end{array}$ & $\begin{array}{c}-0.565^{*} \\
(2.331)\end{array}$ & 0.629 & $\begin{array}{l}-0.491^{*} \\
(2.344)\end{array}$ & 0.701 & 0.000 & $\begin{array}{l}-0.599 * \\
(3.452)\end{array}$ & $\begin{array}{l}-0.581 * \\
(3.441)\end{array}$ & 0.980 & $\begin{array}{c}-0.694 * \\
(4.295)\end{array}$ & 0.984 & 0.118 \\
\hline vw13 & $\begin{array}{l}-0.880^{*} \\
(2.853)\end{array}$ & $\begin{array}{c}-0.811^{*} \\
(2.403)\end{array}$ & 0.436 & $\begin{array}{l}-0.631^{*} \\
(2.350)\end{array}$ & 0.563 & 0.000 & $\begin{array}{l}-0.734 * \\
(2.822)\end{array}$ & $\begin{array}{c}-0.714^{*} \\
(2.849)\end{array}$ & 0.957 & $\begin{array}{c}-0.912^{*} \\
(4.024)\end{array}$ & 0.972 & 0.013 \\
\hline ew13 & $\begin{array}{l}-0.710^{*} \\
(2.610)\end{array}$ & $\begin{array}{c}-0.649^{*} \\
(2.199)\end{array}$ & 0.524 & $\begin{array}{l}-0.567^{*} \\
(2.322)\end{array}$ & 0.634 & 0.000 & $\begin{array}{l}-0.699^{*} \\
(2.664)\end{array}$ & $\begin{array}{l}-0.680^{*} \\
(2.967)\end{array}$ & 0.945 & $\begin{array}{c}-1.000^{*} \\
(4.411)\end{array}$ & 0.959 & 0.047 \\
\hline
\end{tabular}




\section{Table 6 Company analysis and persistence}

The unconditional and conditional Jensen Measures are calculated from the single-index model for equalweighted portfolio of well-diversified Japanese equity funds for each management company. The figures in the parenthesis ( ) are t-statistics adjusted for heteroskedasticity, and [ ] are rankings across the companies. Portfolio ew190 is the equal-weighted portfolio of well-diversified equity funds across all management companies. The performances are measured in percentage per month.

\begin{tabular}{ccccccc}
\hline & & Unconditional & & & Conditional & \\
\hline Company & Jan. 1981- & Jan. 1981- & Jan. 1990- & Jan. 1981- & Jan. 1981- & Jan. 1990- \\
& Dec. 1992 & Dec. 1989 & Dec. 1992 & Dec. 1992 & Dec. 1989 & Dec. 1992 \\
\hline A & -0.483 & -0.305 & -0.609 & -0.493 & -0.304 & -0.683 \\
& $(4.088)[1]$ & $(1.931)[2]$ & $(3.819)[6]$ & $(4.425)[1]$ & $(2.122)[2]$ & $(4.575)[4]$ \\
B & -0.756 & -0.658 & -0.515 & -0.751 & -0.489 & -0.609 \\
& $(2.372)[5]$ & $(1.397)[3]$ & $(2.962)[3]$ & $(2.386)[5]$ & $(1.130)[4]$ & $(3.439)[2]$ \\
C & -0.766 & -0.696 & -0.565 & -0.751 & -0.544 & -0.773 \\
& $(3.356)[6]$ & $(2.044)[6]$ & $(3.042)[5]$ & $(3.269)[5]$ & $(1.807)[6]$ & $(4.134)[7]$ \\
D & -0.736 & -0.660 & -0.617 & -0.768 & -0.589 & -0.743 \\
& $(3.892)[4]$ & $(2.553)[4]$ & $(3.089)[7]$ & $(4.217)[7]$ & $(2.411)[7]$ & $(4.161)[6]$ \\
E & -0.800 & -0.694 & -0.401 & -0.728 & -0.531 & -0.539 \\
& $(3.794)[7]$ & $(2.241)[5]$ & $(2.342)[1]$ & $(3.517)[4]$ & $(1.934)[5]$ & $(3.003)[1]$ \\
F & -0.858 & -0.811 & -0.553 & -0.809 & -0.663 & -0.649 \\
& $(3.490)[8]$ & $(2.112)[8]$ & $(2.903)[4]$ & $(3.255)[8]$ & $(1.906)[8]$ & $(4.290)[3]$ \\
G & -0.512 & -0.283 & -0.840 & -0.564 & -0.136 & -0.961 \\
& $(2.325)[2]$ & $(0.885)[1]$ & $(3.473)[8]$ & $(2.705)[2]$ & $(0.536)[1]$ & $(4.246)[9]$ \\
& & & & & & \\
H & -0.716 & -0.707 & -0.404 & -0.608 & -0.429 & -0.695 \\
& $(3.623)[3]$ & $(2.484)[7]$ & $(2.067)[2]$ & $(3.455)[3]$ & $(1.867)[3]$ & $(3.368)[5]$ \\
& & & & & & \\
& -0.909 & -1.048 & -0.657 & -1.073 & -1.153 & -0.823 \\
& $(2.974)[9]$ & $(2.424)[9]$ & $(2.111)[9]$ & $(3.575)[9]$ & $(2.749)[9]$ & $(3.394)[8]$ \\
\hline ew190 & -0.668 & -0.565 & -0.581 & -0.681 & -0.491 & -0.694 \\
& $(3.959)$ & $(2.331)$ & $(3.441)$ & $(4.240)$ & $(2.344)$ & $(4.295)$ \\
\hline & & & & & &
\end{tabular}




\section{Table 7 Passive strategy portfolios}

The numbers are intercepts (Jensen Measure) of the regressions of 36 passive portfolio excess returns on the value weighted market index that includes both stocks and bonds with a more than one year maturity. The numbers in parentheses are heteroskedasticity-adjusted t-statistics. Among the 36 portfolios, 25 are sorted by size and book-to-market ratio (BE/ME), 6 by earning-price ratio $(\mathrm{E} / \mathrm{P})$, and 5 by book asset to market equity ratio (BA/ME), formed from all stocks in both the first and second sections of the TSE. The excess returns are net of the one-month Gensaki rates. Size 1 (5) has the smallest (largest) market capitalization, BE/ME 1 (5) has the lowest (highest) BE/ME ratio. E/P 1 (5) has the lowest (highest) E/P ratio and BA/ME $1(5)$ has the lowest (highest) leverage. Asterisks $\left(^{*}\right)$ indicate significance at $10 \%$.

\begin{tabular}{|c|c|c|c|c|c|}
\hline & & Panel A & Unconditional & & \\
\hline & $\mathrm{BE} / \mathrm{ME} 1$ & $\mathrm{BE} / \mathrm{ME} 2$ & $\mathrm{BE} / \mathrm{ME} 3$ & $\mathrm{BE} / \mathrm{ME} 4$ & $\mathrm{BE} / \mathrm{ME} 5$ \\
\hline \multirow{2}{*}{ size 1} & 0.673 & $0.860^{*}$ & $1.168 *$ & $0.823^{*}$ & $1.106^{*}$ \\
\hline & (1.342) & (1.734) & $(2.552)$ & (1.907) & $(2.536)$ \\
\hline \multirow[t]{2}{*}{ size 2} & 0.143 & 0.619 & $0.843^{*}$ & $0.795^{*}$ & $0.797^{*}$ \\
\hline & $(0.330)$ & (1.479) & $(2.170)$ & $(1.970)$ & $(2.019)$ \\
\hline \multirow[t]{2}{*}{ size 3} & 0.044 & 0.246 & 0.320 & 0.413 & $0.734^{*}$ \\
\hline & $(0.113)$ & $(0.662)$ & $(0.885)$ & $(1.171)$ & $(1.880)$ \\
\hline \multirow[t]{2}{*}{ size 4} & -0.527 & 0.041 & 0.346 & 0.417 & $0.718^{*}$ \\
\hline & $(-1.408)$ & $(0.135)$ & (1.079) & $(1.367)$ & $(2.276)$ \\
\hline \multirow[t]{2}{*}{ size 5} & $-0.708^{*}$ & -0.105 & 0.131 & $0.522^{*}$ & $0.565^{*}$ \\
\hline & $(-2.577)$ & $(-0.458)$ & $(0.602)$ & (1.803) & $(1.785)$ \\
\hline $\mathrm{E} / \mathrm{P}<0$ & $\mathrm{E} / \mathrm{P} 1$ & $\mathrm{E} / \mathrm{P} 2$ & $\mathrm{E} / \mathrm{P} 3$ & $\mathrm{E} / \mathrm{P} 4$ & $\mathrm{E} / \mathrm{P} 5$ \\
\hline \multirow{6}{*}{$\begin{array}{c}0.745^{*} \\
(1.908)\end{array}$} & $-0.477^{*}$ & -0.170 & 0.055 & 0.287 & $0.491 *$ \\
\hline & $(-2.065)$ & $(-0.684)$ & $(0.262)$ & $(1.390)$ & $(2.000)$ \\
\hline & BA/ME 1 & BA/ME 2 & BA/ME 3 & BA/ME 4 & BA/ME 5 \\
\hline & -0.319 & 0.072 & 0.253 & 0.250 & $0.537 *$ \\
\hline & $(-0.969)$ & $(0.313)$ & $(1.232)$ & $(1.167)$ & $(1.966)$ \\
\hline & & Panel B & Conditional & & \\
\hline & $\mathrm{BE} / \mathrm{ME} 1$ & $\mathrm{BE} / \mathrm{ME} 2$ & $\mathrm{BE} / \mathrm{ME} 3$ & $\mathrm{BE} / \mathrm{ME} 4$ & $\mathrm{BE} / \mathrm{ME} 5$ \\
\hline \multirow[t]{2}{*}{ size 1} & $0.869 *$ & $1.046^{*}$ & $1.361^{*}$ & $0.980^{*}$ & $1.196^{*}$ \\
\hline & $(1.729)$ & $(2.069)$ & (2.928) & (2.196) & (2.735) \\
\hline \multirow[t]{2}{*}{ size 2} & 0.282 & $0.779^{*}$ & $0.929^{*}$ & $0.957^{*}$ & $0.957^{*}$ \\
\hline & $(0.647)$ & $(1.844)$ & $(2.336)$ & $(2.372)$ & $(2.479)$ \\
\hline \multirow[t]{2}{*}{ size 3} & 0.118 & 0.408 & 0.467 & $0.588^{*}$ & $0.922^{*}$ \\
\hline & $(0.299)$ & (1.102) & (1.316) & $(1.660)$ & $(2.431)$ \\
\hline \multirow[t]{2}{*}{ size 4} & -0.424 & 0.180 & $0.514^{*}$ & $0.542^{*}$ & $0.827^{*}$ \\
\hline & $(-1.123)$ & $(0.583)$ & (1.656) & $(1.831)$ & $(2.648)$ \\
\hline \multirow[t]{2}{*}{ size 5} & $-0.725^{*}$ & -0.065 & 0.016 & 0.397 & $0.600^{*}$ \\
\hline & $(-2.749)$ & $(-0.283)$ & $(0.075)$ & $(1.512)$ & (1.935) \\
\hline \multirow{6}{*}{$\begin{array}{c}\mathrm{E} / \mathrm{P}<0 \\
0.931^{*} \\
(2.380)\end{array}$} & $\mathrm{E} / \mathrm{P} 1$ & $\mathrm{E} / \mathrm{P} 2$ & $\mathrm{E} / \mathrm{P} 3$ & $\mathrm{E} / \mathrm{P} 4$ & E/P 5 \\
\hline & $-0.450^{*}$ & -0.111 & -0.001 & 0.253 & $0.403^{*}$ \\
\hline & $(-2.010)$ & $(-0.465)$ & $(-0.003)$ & (1.389) & $(1.733)$ \\
\hline & BA/ME 1 & $\mathrm{BA} / \mathrm{ME} 2$ & BA/ME 3 & $\mathrm{BA} / \mathrm{ME} 4$ & BA/ME 5 \\
\hline & -0.351 & 0.070 & 0.273 & 0.204 & $0.524^{*}$ \\
\hline & $(-1.101)$ & $(0.318)$ & $(1.339)$ & $(0.948)$ & $(1.876)$ \\
\hline
\end{tabular}




\section{Table 8 The 3-factor models}

Panel A reports the estimates for the conditional and unconditional beta for the aggregate mutual fund portfolios from the 3 -factor model. The coefficients $\beta, \beta^{\mathrm{SMB}}$, and $\beta^{\mathrm{HML}}$ (subscript $\mathrm{j}$ is omitted) are unconditional betas from the following regression:

$$
r_{j, t+1}=\alpha_{j}+\beta_{j} r_{m, t+1}+\beta_{j}^{\mathrm{SMB}} \mathrm{SMB}_{t+1}+\beta_{j}^{\mathrm{HML}} \mathrm{HML}_{t+1}+\varepsilon_{j, t+1},
$$

where $r_{j, t+1}$ is the excess return for the $\mathrm{j}$-th mutual fund, $r_{m, t+1}$ is the excess return of the value-weighted market portfolio, $\mathrm{SMB}_{\mathrm{t}}$ and $\mathrm{HML}_{\mathrm{t}}$ are the mimicking factors related to the size and book-to-market ratios, respectively. The coefficients $b_{1}, b_{1}$ SMB and $b_{1}{ }^{\mathrm{HML}}$ are average conditional betas with respect to the 3 factors, and $b_{2}, b_{2} \mathrm{SMB}$ and $b_{2}{ }^{\mathrm{HML}}$ are the vectors of beta responsive coefficients from the following conditional model:

$$
r_{j, t+1}=a_{j}+\left(b_{1 j}+b_{2 j}{ }^{\prime} z_{t}\right) r_{m, t+1}+\left(b_{1 j}^{\mathrm{SMB}}+b_{2 j}^{\mathrm{SMB}} z_{t}\right) \mathrm{SMB}_{t+1}+\left(b_{1 j}^{\mathrm{HML}}+b_{2 j}^{\mathrm{HML}} z_{t}\right) \mathrm{HML}_{t+1}+\varepsilon_{j, t+1} .
$$

The vector of information variables, $z$, includes dividend yield, one-month Gensaki rate, the long-short spread and the January dummy. Heteroskedasticity-adjusted t-statistics are in the parenthesis. Asterisks $\left.{ }^{*}\right)$ indicate significance at $10 \%$ level. Panel B reports the number of positive and negative coefficients from the 64 and its subset of 13 individual funds. The significance level is $10 \%$.

\begin{tabular}{|c|c|c|c|c|c|c|c|c|c|c|}
\hline & & Unco & itional & & & & Con & ional & & \\
\hline Panel A & $\alpha$ & $\beta$ & $\beta^{\mathrm{SMB}}$ & $\beta^{\mathrm{HML}}$ & $\mathrm{R}^{2}$ & $a$ & $b_{l}$ & $b_{I}^{\text {SMB }}$ & $b_{I}{ }^{\mathrm{HN}}$ & $\mathrm{R}^{2}$ \\
\hline (All categ & ries) & & & & & & & & & \\
\hline vw800 & $-0.478^{*}$ & $0.927^{*}$ & $-0.080^{*}$ & -0.089 & & $-0.563^{*}$ & $1.045^{*}$ & $-0.158^{*}$ & $-0.211^{*}$ & \\
\hline & $(2.286)$ & (18.291) & $(2.537)$ & (1.186) & 0.819 & $(4.4$ & (16.515) & $(4.382)$ & $(3.552)$ & 0.897 \\
\hline ew800 & $-0.461 *$ & $0.838^{*}$ & -0.042 & -0.026 & & $-0.525^{*}$ & $0.920^{*}$ & $-0.138^{*}$ & $-0.140^{*}$ & \\
\hline & $(2.826)$ & (16.498) & $(1.309)$ & $(0.379)$ & 0.798 & $(4.551)$ & (14.063) & (4.078) & $(2.750)$ & 0.897 \\
\hline vw64 & $-0.516^{*}$ & $0.862^{*}$ & $-0.118^{*}$ & -0.048 & & 0.5 & $1.034^{*}$ & $-0.198^{*}$ & $-0.197^{*}$ & \\
\hline & $(2.581)$ & (14.545) & $(3.025)$ & $(0.546)$ & 0.745 & $(4$. & (14.723) & (4.744) & (2.904) & 0.858 \\
\hline ew64 & $-0476^{*}$ & $0.819^{*}$ & $-0.078^{*}$ & -0.009 & & $-0.571^{*}$ & $0.909 *$ & $-0.196^{*}$ & $-0.160^{*}$ & \\
\hline & (2.474) & (14.343) & $(2.021)$ & $(0.107)$ & 0.732 & $(4.046)$ & (11.022) & $(4.502)$ & $(2.655)$ & 0.858 \\
\hline (Well-div & rsified Jap & anese equi & funds) & & & & & & & \\
\hline vw190 & $-0.603 *$ & $1.108^{*}$ & -0.046 & $-0.214^{*}$ & & -0.7 & $1.237^{*}$ & $-0.122 *$ & $-0.359 *$ & \\
\hline & (3.096) & $(20.228)$ & (1.201) & $(2.442)$ & 0.825 & $(4$ & (14.119) & $(2.471)$ & $(4.452)$ & 0.887 \\
\hline ew190 & $-0.534^{*}$ & $1.078 *$ & -0.056 & $-0.134^{*}$ & & $-0.639^{*}$ & $1.191 *$ & $-0.143^{*}$ & $-0.274^{*}$ & \\
\hline & $(2.988)$ & $(20.999)$ & $(1.540)$ & (1.844) & 0.835 & $(4.352)$ & $(14.629)$ & (3.277) & $(4.252)$ & 0.898 \\
\hline vw13 & $-0.772 *$ & $1.032 *$ & $-0.093^{*}$ & -0.151 & & -0.9 & $1.251^{*}$ & $-0.162^{*}$ & $-0.336^{*}$ & \\
\hline & $(3.00$ & (13.688) & $(1.907)$ & $(1.300)$ & 0.717 & $(4$ & (12.781) & (2.724) & (3.412) & 0.834 \\
\hline ew13 & $-0.583 *$ & $0.985 *$ & $-0.102 *$ & -0.087 & & $-0.729 *$ & $1.158^{*}$ & $-0.201^{*}$ & $-0.271^{*}$ & \\
\hline & $(2.685)$ & (15.193) & $(2.389)$ & $(0.973)$ & 0.745 & $(4.262)$ & (12.131) & (3.852) & $(3.421)$ & 0.851 \\
\hline Pan & $\begin{array}{l}\text { The n } \\
\text { [The } n\end{array}$ & of $\mathrm{p}$ & and & ive & ien & $\begin{array}{l}54 \text { in } \\
\text { und }\end{array}$ & al fur & & & \\
\hline & $\alpha$ & $\beta$ & $\beta^{\text {SMB }}$ & $\beta^{\mathrm{HML}}$ & & $a$ & $b_{1}$ & $b_{1}^{\text {SMB }}$ & $b_{I}{ }^{\mathrm{HML}}$ & \\
\hline & $4[0]$ & 64 [13] & $25[1]$ & $32[4]$ & & $1[0]$ & $62[13]$ & $9[1]$ & $12[0]$ & \\
\hline Sig. pos. & $0[0]$ & 62 [13] & $10[0]$ & $7[0]$ & & $0[0]$ & $61[13]$ & $0[0]$ & $4[0]$ & \\
\hline & 60[ & $0[0]$ & 39 [12] & $32[9]$ & & 63 & $2[0]$ & 55 [12] & 52 [13] & \\
\hline Sig. neg. & $32[8]$ & $0[0]$ & $22[9]$ & $3[3]$ & & $45[11]$ & $0[0]$ & 38 [9] & 30 [9] & \\
\hline
\end{tabular}

Period: Jan. 1981 - Dec. 1992 


\section{Table 9 Dilution effect on the net asset value: A bootstrap experiment}

The first column, $N A V_{0} / \bar{P}_{0}$, is the premium (or discount) of the current NAV over the past average of after tax prices of the mutual fund share. This is the initial premium set at the beginning of the simulated series of 144 months. The fund inflow rate $(\alpha)$ is the ratio of inflow per month to the total asset outstanding. The initial age of the fund is set equal to 10 years (or 120 months). One plus the rate of return of NAV is calculated using the following formula for month $t$ :

$$
N A V_{\mathrm{t}} / N A V_{\mathrm{t}-1}=\left(1+r_{\mathrm{t}}\right)-\alpha(0.2) \operatorname{Max}\left[\left(1+r_{\mathrm{t}}\right) N A V_{\mathrm{t}-1}-\bar{P}_{\mathrm{t}-1}, 0\right] / N A V_{\mathrm{t}-1}
$$

where $r_{\mathrm{t}}$ is the rate of return of the managed portfolio, and $\bar{P}_{\mathrm{t}}=\left\{\bar{P}_{\mathrm{t}-1}(120+\mathrm{t}-1)+P_{\mathrm{t}}\right\} /(120+\mathrm{t})$ where $P_{\mathrm{t}}=N A V_{\mathrm{t}}-(0.2) \operatorname{Max}\left[\left(1+r_{\mathrm{t}}\right) N A V_{\mathrm{t}-1}-\bar{P}_{\mathrm{t}-1}, 0\right]$ for $\mathrm{t}=1 \ldots 144$. For each bootstrap experiment, $r_{\mathrm{t}}$ is drawn without replacement from the return distribution of the value-weighted portfolio that comprises of stocks, bonds and convertible bonds from January 1981 to December 1992. The simulated time series average of the

dilution effect, $-\alpha(0.2) \operatorname{Max}\left[\left(1+\mathrm{r}_{\mathrm{t}}\right) N A V_{\mathrm{t}-1}-\bar{P}_{\mathrm{t}-1}, 0\right] / N A V_{\mathrm{t}-1}$, is calculated for each experiment. The numbers in Panel A are means and standard deviations (in the parenthesis) from 1,000 experiments for various sets of parameters. For each case, the null hypothesis that the simulated distribution of this number is normal cannot be rejected at the 5\% significance level using Jarque-Bera statistics for the test of normality. Panel B reports the p-values of the dilution effect at $-0.6 \%$ per month $(-7.44 \%$ p.a.) and $-0.3 \%$ per month $(-3.66 \%$ p.a.) from the experiment.

Panel A

\begin{tabular}{|c|c|c|c|}
\hline Fund inflow rate & $\alpha=0.01$ & 0.05 & 0.10 \\
\hline$\left(N A V_{0} / \bar{P}_{0^{-}} 1\right)$ & \multicolumn{3}{|c|}{ (\% per month) } \\
\hline $10 \%$ & $\begin{array}{c}-0.067 \\
(0.012)\end{array}$ & $\begin{array}{c}-0.271 \\
(0.050)\end{array}$ & $\begin{array}{c}-0.424 \\
(0.073)\end{array}$ \\
\hline $0 \%$ & $\begin{array}{c}-0.059 \\
(0.012)\end{array}$ & $\begin{array}{c}-0.242 \\
(0.050)\end{array}$ & $\begin{array}{c}-0.382 \\
(0.074)\end{array}$ \\
\hline$-10 \%$ & $\begin{array}{c}-0.051 \\
(0.013) \\
\end{array}$ & $\begin{array}{c}-0.211 \\
(0.050) \\
\end{array}$ & $\begin{array}{r}-0.336 \\
(0.073) \\
\end{array}$ \\
\hline \multicolumn{4}{|l|}{ Panel B } \\
\hline Fund inflow rate & $\alpha=0.01$ & 0.05 & 0.10 \\
\hline$\left(N A V_{0} / \bar{P}_{0}-1\right)$ & & $\begin{array}{l}\text { ffect }<-0 \\
\text { ffect }<-0\end{array}$ & \\
\hline $10 \%$ & $\begin{array}{c}0.00 \\
{[0.00]}\end{array}$ & $\begin{array}{c}0.00 \\
{[0.28]}\end{array}$ & $\begin{array}{c}0.01 \\
{[0.97]}\end{array}$ \\
\hline $0 \%$ & $\begin{array}{c}0.00 \\
{[0.00]}\end{array}$ & $\begin{array}{c}0.00 \\
{[0.11]}\end{array}$ & $\begin{array}{c}0.00 \\
{[0.84]}\end{array}$ \\
\hline$-10 \%$ & $\begin{array}{c}0.00 \\
{[0.00]}\end{array}$ & $\begin{array}{c}0.00 \\
{[0.05]}\end{array}$ & $\begin{array}{c}0.00 \\
{[0.69]}\end{array}$ \\
\hline
\end{tabular}


Figure 1 Japanese open-type mutual funds

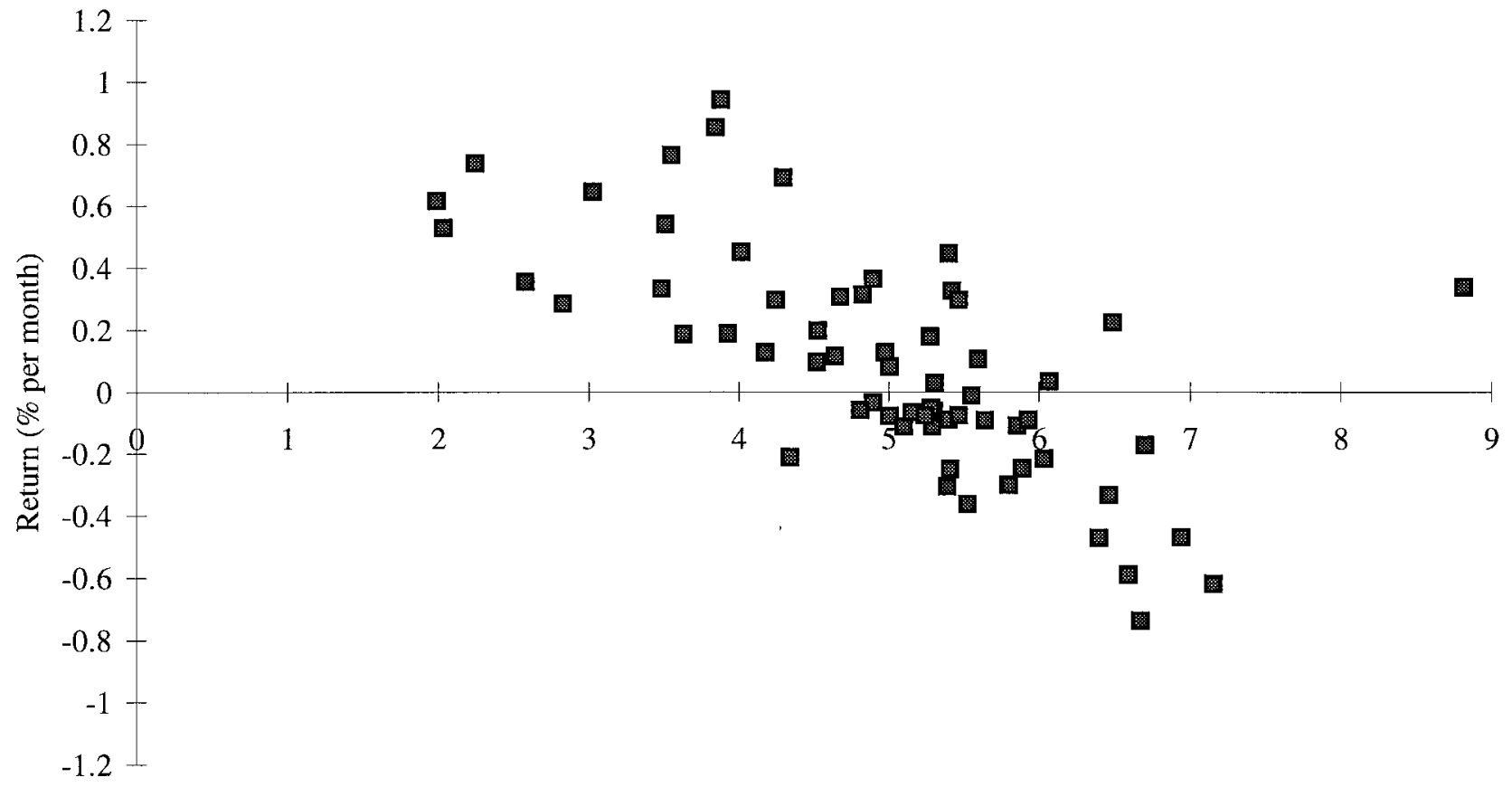

Standard Deviation 
Figure 2 Jensen measures: Single factor model

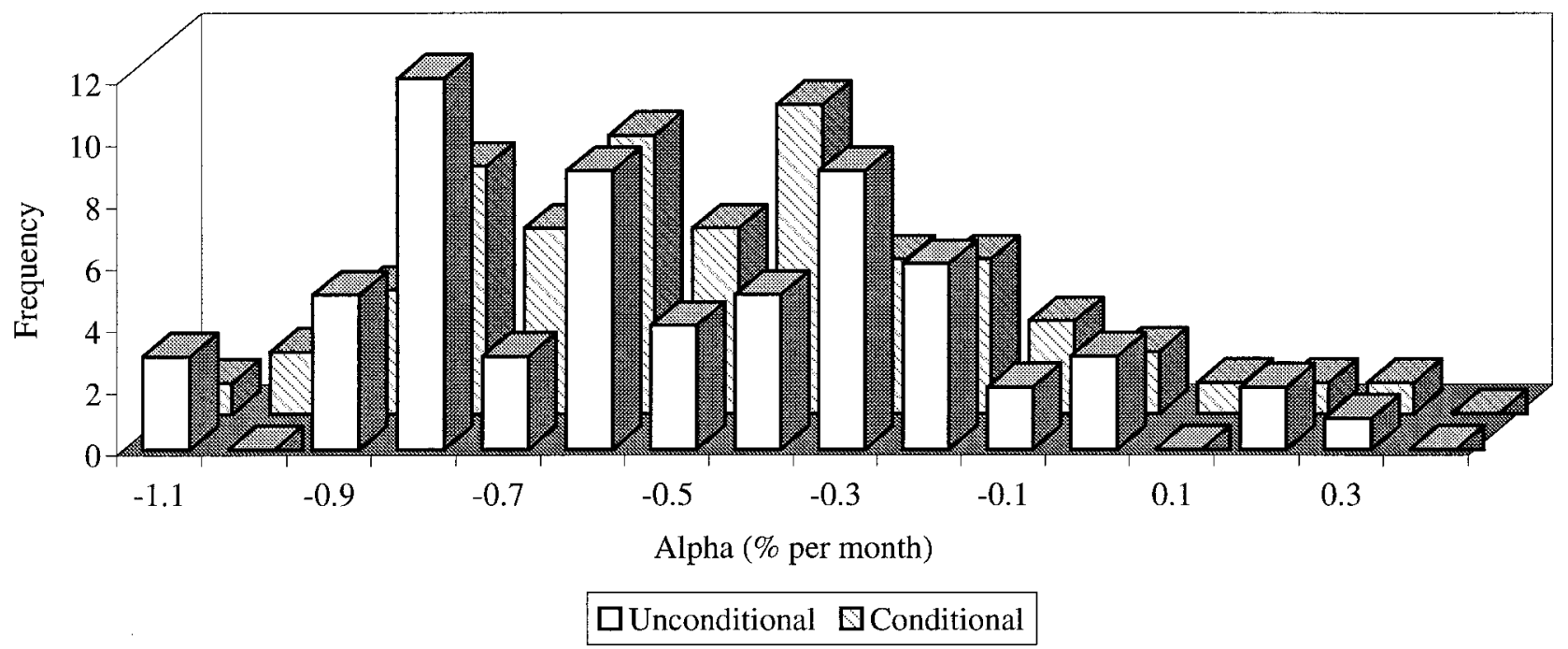


Figure 3 Jensen measures: 3-factor model

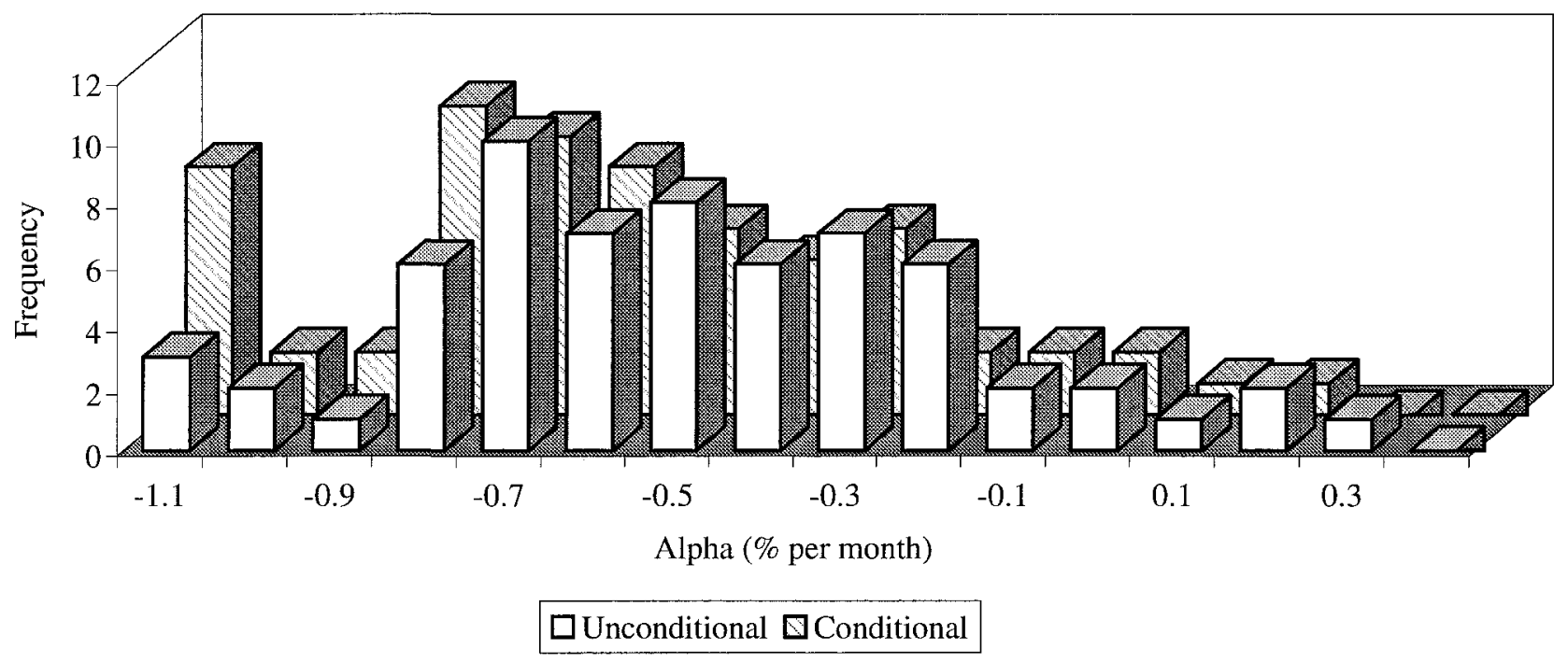

